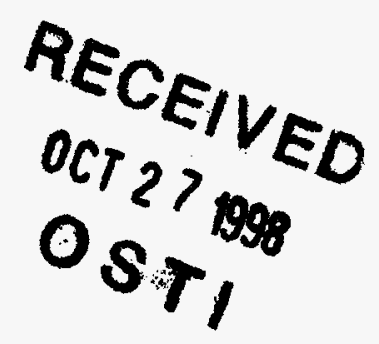

\title{
COMPILATION OF EXISTING CHEMICAL AGENT GUIDELINES TABLE AS OF SEPTEMBER 1997
}

Cheri Bandy Foust

Energy Division

Oak Ridge National Laboratory
WANAGED ANO OPERMTED BY LOCKHEED WARTIN ENERGY RESEARCH CORPORATION FOB THE UNITEO STATES

DEPARTMENT OF ENERGY

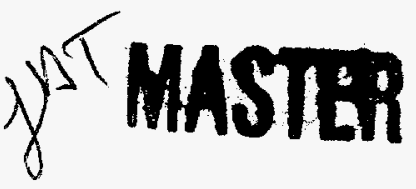

DITTRBUTLN OF THIS DOCAMEAT is UALMTTED 
This report has been reproduced directly from the best availabie copy.

Available to DOE and DOE contractors from the Office of Scientific and Technical Information, P. O. Box 62, Oak Ridge, TN 37831; prices available from (615) 576-8401, FTS 626-8401.

Available to the public from the National Technical Information Service, U.S. Department of Commerce, 4284 Port Royal Rd., Springfield, VA 22161.

This report was prepared as an account of work sponsored by an agency of the United States Government. Neither the United States Government nor any agency thereof, nor any of their employees, makes any warranty, expressed or implied, or assumes any legal liability or responsibility for the accuracy, completeness, or usefulness of any information, apparatus, product, or process disclosed, or represents that its use would not infringe privately owned rights. Reference herein to any specific commercial product, process, or service by trade name, trademark, manufacturer, or otherwise, does not necessarily constitute or imply its endorsement, recommendation, or favoring by the United Sates Government or any agency thereof. The views and opinions of the authors expressed herein do not necessarily state or reflect those of the United States Government or any agency therefore. 


\section{DISCLAIMER}

Portions of this document may be illegible in electronic image products. Images are produced from the best available original document. 
ORNL/TM-13649

\title{
COMPILATION OF EXISTING CHEMICAL AGENT GUIDELINES TABLE AS OF SEPTEMBER 1997
}

\author{
Cheri Bandy Foust \\ Oak Ridge National Laboratory
}

August 1998

Prepared for the

Federal Emergency Management Agency

Regulatory Service Coordination Unit

and

U.S. Army Center for Health Promotion and Preventive Medicine

by

OAK RIDGE NATIONAL LABORATORY

Oak Ridge, Tennessee 37831

managed by

LOCKHEED MARTIN ENERGY RESEARCH CORP.

For the

U.S. DEPARTMENT OF ENERGY

under contract No. DE-AC05-96OR22464 



\section{PREFACE}

The perceived lack of applicable chemical agent guidelines, standards, interim standards, and control limits, has been an area of concern within the Chemical Stockpile Emergency

Preparedness Program (CSEPP) planning community for some time. Despite the fact that there are a number of established concentration values, the appropriate uses of those values are not well documented, limiting their benefit to CSEPP.

The Oak Ridge National Laboratory (ORNL) in collaboration with the U.S. Army Center for Health Promotion and Preventive Medicine (USACHPPM), was tasked by the Federal Emergency Management Agency (FEMA) with identifying published chemical warfare agent guidelines, standards, interim standards, and control limits, and compiling that material along with information regarding their appropriate uses within the CSEPP, into a reference document. This document provides references, but does not provide the data and assumptions on which the exposure guidelines were based, or comment on the rationale or appropriateness of the given values. To do so is beyond the scope of work for this task. The Army accepts the accuracy of this version of the document as per its defined purpose. However, the Army has established a Work Group to assess the accuracy of the information contained in the source references. As information is clarified/modified, future versions of the document will be updated to reflect any necessary changes. 



\section{ACKNOWLEDGMENTS}

The Oak Ridge National Laboratory (ORNL) Energy Division gratefully acknowledges contributions to this document from a number of individuals. ORNL wishes to acknowledge the valuable assistance and guidance received from Veronique Hauschild (Environmental Risk Assessment and Communication) and Jennifer Lindado Keetley (Hazardous and Medical Waste Program) of the U.S. Army Center for Health Promotion and Preventive Medicine (USACHPPM). ORNL wishes to thank William J. B. Pringle (Environmental and Monitoring Office) and Dr. J. Richard Ward (Alternative Technologies and Approaches) of the U.S. Army Manager for Chemical Demilitarization Office; and other Army organizations for serving as reviewers. ORNL is also indebted to Dr. Annetta Watson (Life Sciences) of ORNL for serving as reviewer and providing technical guidance. Karen Bowman (Energy Division) of ORNL deserves thanks for her able editorial work and competent handling of a difficult assignment. 



\section{TABLE OF CONTENTS}

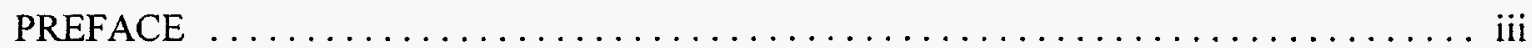

ACKNOWLEDGMENTS $\ldots \ldots \ldots \ldots \ldots \ldots \ldots \ldots \ldots \ldots \ldots \ldots \ldots \ldots \ldots$

ACRONYMS AND ABBREVIATIONS $\ldots \ldots \ldots \ldots \ldots \ldots \ldots \ldots \ldots \ldots \ldots \ldots \ldots \ldots \ldots \ldots$

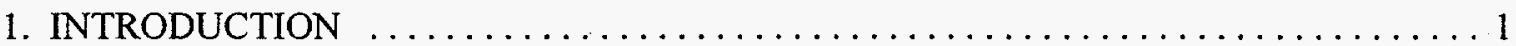

APPENDIX A: DETAILED BACKGROUND INFORMATION ON THE

COMPILATION OF EXISTING CHEMICAL AGENT GUIDELINES

AS OF SEPTEMBER 1997 TABLE

APPENDIX B: USACHPPM "JUST THE FACTS" INFORMATION SHEET

ON REFERENCE DOSE SEPTEMBER 1997

B-1 



\title{
ACRONYMS AND ABBREVIATIONS
}

\author{
$\mathrm{C} \quad$ celsius \\ CDC Centers for Disease Control and Prevention \\ CFR Code of Federal Regulations \\ ChE cholinesterase \\ COT Committee on Toxicology \\ CSEPP Chemical Stockpile Emergency Preparedness Program \\ DA U.S. Department of the Army \\ DHHS U.S. Department of Health and Human Services \\ EPA Environmental Protection Agency \\ F fahrenheit \\ FEMA Federal Emergency Management Agency \\ FR Federal Register \\ GA the chemical dimethylphosphoramidocyanidate \\ GB the chemical isopropyl methylphosphonofluoridate \\ GD the chemical phosphonofluoridic acid, methyl-1,2,2-trimethypropyl ester \\ $\mathrm{H}$ \\ the chemical levinstein mustard; mixture of $70 \%$ bis(2-chloroethyl) sulfide and \\ HD levinstein mustard of bis(2-chloroethyl) sulfide \\ HT a mixture of HD and bis(2-chloroethylthioethyl ether \\ IDLH immediately dangerous to life or health \\ $\mathrm{L}$ \\ L/day \\ $\mathrm{LD}_{01}$ \\ $\mathrm{m}^{3}$ \\ the chemical dichloro (2-chlorovinyl) arsine \\ liter per day \\ calculated dose that is expected to cause death in $1 \%$ of the exposed population \\ $\mu \mathrm{g} / \mathrm{kg} /$ day microgram chemical per kilogram body weight per day \\ $\mu \mathrm{g} / \mathrm{L}$ \\ $\mathrm{mg}$ \\ $\mathrm{mg} / \mathrm{kg} /$ day \\ $\mathrm{mg} / \mathrm{m}^{3}$ \\ $\mathrm{mg}-\mathrm{min} / \mathrm{m}^{3}$ \\ $\min$ \\ PPE \\ RAGS \\ RBC-ChE \\ RfCs \\ RfDs \\ cubic meter \\ microgram per liter \\ milligram \\ milligram chemical per kilogram body weight per day \\ milligram per cubic meter of air \\ milligram minutes per cubic meter of air \\ minute \\ personal protective equipment \\ SCBA self-contained breathing apparatus \\ TWA \\ Risk Assessment Guidance for Superfund \\ red blood cell cholinesterase \\ reference concentrations \\ reference doses \\ time weighted average \\ USACHPPM U.S. Army Center for Health Promotion and Preventive Medicine \\ $\mathrm{VX}$ \\ the chemical phosphonothioic acid, methyl-, S-(2-bis(1- \\ methylethyl)amino)ethyl)0-ethylester
}





\section{PURPOSE AND BACKGROUND}

Public Law 99-145 requires the U.S. Department of the Army to dispose of the lethal chemical agents and munitions stockpile stored at eight Army installations throughout the continental United States and Johnston Atoll in the Pacific. Recognition by the U.S. Army that a potential threat to the public from continued storage was greater than the threat from transportation and demilitarization of chemical agents gave rise to the Chemical Stockpile Emergency Preparedness Program (CSEPP). CSEPP is a community emergency preparedness program complementing the Department of Defense's initiative to destroy domestic stockpiles of aged chemical warfare agent munitions. The Federal Emergency Management Agency (FEMA) and the U.S. Army jointly coordinate and direct the CSEPP. The Compilation of Existing Chemical Agent Guidelines Table was developed under the direction of FEMA and the U.S. Army Center for Health Promotion and Preventive Medicine (USACHPPM).

The purpose of this Table is to identify established chemical warfare agent guidelines, standards, and interim standards as of September 1997, and place them in an explanatory context for ready use by the CSEPP community. This Table summarizes and organizes information from numerous agencies and review bodies responsible for recommending exposure guidelines [e.g., The Centers for Disease Control and Prevention (CDC), Committee on Toxicology (COT), Environmental Protection Agency (EPA), FEMA, Army and other federal agencies]. This Table provides references for the interested reader, but does not provide data and assumptions on which exposure guidelines were based, or comment on the rationale or appropriateness of the given values. To do so is beyond the scope of work for this task.

This Table provides a comprehensive list of military and civilian chemical agent guidelines, standards, interim standards, and control limits relevant to CSEPP (Table category definitions below). This Table was developed to assist CSEPP state, local, and Army installation planners in formulating and coordinating plans for chemical agent events that may occur at the eight chemical agent stockpile storage locations in the continental United States.

This Table is a "living document." The Table developers recommend it be periodically updated to reflect new or revised guidelines, standards, interim standards, and control limits. Some guidelines (standards, interim standards, etc.,) are continually under review as more information is acquired and as technology advances detection capabilities. Please contact Karen Cleveland of FEMA [(202) 646-3970 or karen.cleveland@fema.gov] for future editions, questions, etc. This Table was compiled by Cheri Bandy Foust of the Oak Ridge National Laboratory at the request of FEMA in collaboration with Veronique Hauschild and Jennifer Lindado Keetley of USACHPPM [(410)671-5213 or Veronique_Hauschild@chppm-ccmail.apgea.army.mil]. For more information on each Table entry, please see Appendix A.

Control Limit. A recommendation for protecting human health from adverse effects of exposure to chemical agents. A measure established by the CDC (DHHS); compliance is not mandatory.

Guideline. A recommendation from a review body (e.g., Committee on Toxicology) providing guidance and information for use in establishing acceptable conduct or policy that does not endanger public and/or environmental health. A guideline is not a mandatory requirement.

Military Guideline. A recommendation from a military authority providing guidance and information for use in establishing acceptable military conduct or policy. A guideline is not a mandatory requirement. 
Interim Military Standard. A measure established by a military authority to serve as a temporary standard until final requirements are approved and adopted; compliance is usually mandatory.

Military Standard. A measure established by a military authority; military compliance is mandatory. A limit that cannot be exceeded without endangerment or action. 
COMPILATION OF EXISTING CHEMICAL AGENT GUIDELINES - SEPTEMBER 1997

\begin{tabular}{|c|c|c|c|c|}
\hline \multicolumn{5}{|c|}{ AIRBORNE EXPOSURE LIMITS } \\
\hline Category' & $\begin{array}{c}\text { Title } \\
\text { (References footnoted; see page 22) }\end{array}$ & & Information & Comments \\
\hline $\begin{array}{l}\text { Control } \\
\text { Limit }\end{array}$ & $\begin{array}{l}\text { CONTROL LIMITS FOR CHEMICAL } \\
\text { AGENTS FOR WORKERS IN } \\
\text { MILLIGRAMS PER CUBIC METER OF } \\
\left.\text { AIR (mg/ } \mathrm{m}^{3}\right)^{\circ}{ }^{a} \\
\text { Application: These limits are designed to } \\
\text { protect the worker from unsafe } \\
\text { concentrations of chemical agent in the } \\
\text { work environment. Workers can be } \\
\text { exposed to concentrations at or below } \\
\text { these levels for } 8 \text { hours a day without } \\
\text { suffering ill effects. The CDC concludes } \\
\text { there to be little risk either of adverse } \\
\text { health effects from long-term exposure to } \\
\text { low doses or of delayed health effects } \\
\text { from acute exposure. }\end{array}$ & $\begin{array}{l}\text { Agent } \\
\text { GA, GB } \\
V X \\
H, H D, H T \\
L \\
\text { Averaging time: }\end{array}$ & $\begin{array}{l}\text { Workers } \\
1 \times 10^{-4} \mathrm{mg} / \mathrm{m}^{3} \\
1 \times 10^{-5} \mathrm{mg} / \mathrm{m}^{3} \\
3 \times 10^{-3} \mathrm{mg} / \mathrm{m}^{3} \\
3 \times 10^{-3} \mathrm{mg} / \mathrm{m}^{3} \\
8 \mathrm{hr} \text { time weighted average (TWA) }\end{array}$ & $\begin{array}{l}\text { The CDC stated in their Final } \\
\text { Recommendations for Protecting Human } \\
\text { Health and Safety Against Potential } \\
\text { Adverse Effects of Long-Term Exposure } \\
\text { to Low Doses of Agents GA, GB, GD, } \\
V X, \text { Mustard Agents (H, HD, HT) and } \\
\text { Lewisite (L), that citizens near military } \\
\text { depots where chemical weapons are } \\
\text { stored expressed concerns about the } \\
\text { potential for delayed effects of acute } \\
\text { exposure and about the potential health } \\
\text { effects of long-term exposure to low } \\
\text { doses of agents. Low dose means an } \\
\text { airborne concentration of agent below } \\
\text { the control limits. } \\
\text { The CDC concludes human health will } \\
\text { be adequately protected from exposure to } \\
G A, G B, \text { and VX vapor at the } \\
\text { concentrations listed. Even long-term } \\
\text { exposure to these concentrations would } \\
\text { not create any adverse health effects. The } \\
C D C \text { concludes the work place limits for } \\
\text { nutstard agent appear to provide } \\
\text { adequate protection for workers during } \\
\text { the limited time of potential exposure } \\
\text { prior to disposal of these lethal agents. } \\
\text { HT is measured as HD. } \\
\text { See military standard, military airborne } \\
\text { exposure limits for unmasked chemical } \\
\text { agent workers. These CDC values have } \\
\text { been incorporated by the military. The } \\
\text { military added standards for GD. }\end{array}$ \\
\hline
\end{tabular}


COMPILATION OF EXISTING CHEMICAL AGENT GUIDELINES -SEPTEMBER 1997

\begin{tabular}{|c|c|c|c|c|}
\hline Category & $\begin{array}{c}\text { Title } \\
\text { (References footnoted; see page 22) }\end{array}$ & & Information & Comments \\
\hline \multicolumn{5}{|c|}{ AIRBORNE EXPOSURE LIMITS (continued) } \\
\hline $\begin{array}{l}\text { Control } \\
\text { Limit }\end{array}$ & $\begin{array}{l}\text { CONTROL LIMITS FOR CHEMICAL } \\
\text { AGENTS FOR THE GENERAL } \\
\text { POPULATION IN mg/mi." } \\
\text { Application: These limits are designed to } \\
\text { protect the general population } \\
\text { (including children and elderly) from } \\
\text { long-tern exposure to low doses of } \\
\text { chemical agent. The general population } \\
\text { may be exposed to concentrations at or } \\
\text { below these levels without suffering } \\
\text { effects. The CDC concludes there to be } \\
\text { little risk either of adverse health effects } \\
\text { from long-term exposure to low doses or } \\
\text { of delayed health effects from acute } \\
\text { exposure. }\end{array}$ & $\begin{array}{l}\text { Agent } \\
G A, G B \\
V X \\
H, H D, H T \\
L \\
\text { Averaging time: }\end{array}$ & $\begin{array}{l}\text { General population } \\
3 \times 10^{-6} \mathrm{mg} / \mathrm{m}^{3} \\
3 \times 10^{-6} \mathrm{mg} / \mathrm{m}^{3} \\
1 \times 10^{-4} \mathrm{mg} / \mathrm{m}^{3} \\
3 \times 10^{-3} \mathrm{mg} / \mathrm{m}^{3} \\
72 \mathrm{hr} \text { time weighted average (TWA) }\end{array}$ & $\begin{array}{l}\text { The CDC stated in their Final } \\
\text { Recommendations for Protecting Human } \\
\text { Health and Safety Against Potential } \\
\text { Adverse Effects of Long-Term Exposure } \\
\text { to Low Doses of Agents GA, GB, GD, } \\
V X, \text { Mustard Agents (H, HD, HT) and } \\
\text { Lewisite (L), that citizens near military } \\
\text { depots where chemical weapons are } \\
\text { stored expressed concerns about the } \\
\text { potential for delayed effects of acute } \\
\text { exposure and about the potential health } \\
\text { effects of long-term exposure to low } \\
\text { doses of agents. Low dose means an } \\
\text { airborne concentration of agent below } \\
\text { the control limits. } \\
\text { The CDC concludes human health will } \\
\text { be adequately protected from exposure to } \\
\text { GA, GB, and VX vapor at the } \\
\text { concentrations listed. Even long-term } \\
\text { expostre to these concentrations would } \\
\text { not create any adverse health effects. The } \\
\text { CDC concludes control of stack } \\
\text { emissions and the work place air in } \\
\text { accordance with the limits for mustard } \\
\text { agent will amply protect the general } \\
\text { population lono meters or more from a } \\
\text { demilitarizalion site. } \\
\text { HT is measured as HD. } \\
\text { See military standard, military airborne } \\
\text { exposure limits for non-agent workers } \\
\text { and general population. The CDC values } \\
\text { have been incorporated by the military. } \\
\text { The military added standards for GD. }\end{array}$ \\
\hline
\end{tabular}


COMPILATION OF EXISTING CHEMICAL AGENT GUIDELINES - SEPTEMBER 1997

\begin{tabular}{|c|c|c|c|}
\hline Category & $\begin{array}{c}\text { Title } \\
\text { (References footnoted; see page 22) }\end{array}$ & Information & Comments \\
\hline \multicolumn{4}{|c|}{ AIRBORNE EXPOSURE LIMITS (continued) } \\
\hline $\begin{array}{l}\text { Control } \\
\text { Limit }\end{array}$ & $\begin{array}{l}\text { ALLOWABLESTACK } \\
\text { CONCENTRATIONS IN mg/m } \mathrm{m}^{3} \text { FOR } \\
\text { CHEMICAL AGENTS. } \\
\text { Application: To restrict incinerator } \\
\text { emissions to concentrations well below } \\
\text { those that would endanger public health. }\end{array}$ & $\begin{array}{ll}\text { Agent } & \text { General population } \\
\text { GA, GB } & 3 \times 10^{-4} \mathrm{mg} / \mathrm{m}^{3} \\
V X & 3 \times 10^{-4} \mathrm{mg} / \mathrm{m}^{3} \\
H, H D, H T & 3 \times 10^{-2} \mathrm{mg} / \mathrm{m}^{3} \\
L & 3 \times 10^{-2} \mathrm{mg} / \mathrm{m}^{3} \\
& \\
\text { HT is measured as HD. }\end{array}$ & $\begin{array}{l}\text { Usually allowable stack concentrations } \\
\text { prove more restrictive than a limit set on } \\
\text { health bases alone. These levels have } \\
\text { been evaluated through air dispersion } \\
\text { modeling of worst case credible events } \\
\text { and conditions specific to each site to } \\
\text { ensure that the control limits for general } \\
\text { population and workers would not be } \\
\text { exceeded as a consequence of releases at } \\
\text { or below the allowable stack } \\
\text { concentrations. } \\
\text { These limits are primarily an } \\
\text { engineering control limit. These limits } \\
\text { should be attainable by a well-designed, } \\
\text { well-operated incineration facility; give } \\
\text { an early indication of upset conditions; } \\
\text { and be accurately measurable in a timely } \\
\text { manner. }\end{array}$ \\
\hline \multicolumn{4}{|c|}{$\begin{array}{l}\text { Control Limit. A recommendation for protecting human health from adverse effects of exposure to chemical agents. A measure established by the CDC (DHHS); } \\
\text { compliance is not mandatory. }\end{array}$} \\
\hline $\begin{array}{l}\text { Military } \\
\text { Standard }\end{array}$ & $\begin{array}{l}\text { MILITARY IMMEDLATELY } \\
\text { DANGEROUS TO LIFE OR HEALTH } \\
\text { (IDLH). } \\
\text { Application: To indicate to military } \\
\text { personnel the levels at which a self- } \\
\text { contained breathing apparatus (SCBAS) } \\
\text { or supplied air respirators are required. }\end{array}$ & $\begin{array}{lc}\text { Agent } & \text { Concentration } \\
\text { GA, GB } & 0.2 \mathrm{mg} / \mathrm{m}^{3} \\
G D & 0.06 \mathrm{mg} / \mathrm{m}^{3} \\
V X & 0.02 \mathrm{mg} / \mathrm{m}^{3} \\
& \\
& \\
& \\
\text { wD } \mathrm{H} / \mathrm{L} \text { IDLH values not formally established since } \\
\text { workers will already be required to wear SCBAs or } \\
\text { supplied air respirators at concentrations over } 0.003 \\
\left.\text { mg/m (or } 3 \times 10^{-3} \mathrm{mg} / \mathrm{m}^{3}\right) \text { due to concerns over } \\
\text { carcinogenicity. }\end{array}$ & $\begin{array}{l}\text { These values were established by the } \\
\text { Army Surgeon General for military } \\
\text { personnel solely for the purpose of } \\
\text { establishing the concentrations at which } \\
\text { SCBAs or supplied air respirators are } \\
\text { required. }\end{array}$ \\
\hline \multicolumn{4}{|c|}{$\begin{array}{l}\text { Military Standard. A measure established by a military authority; military compliance is mandatory. A limit that cannot be exceeded without endangerment or } \\
\text { action. }\end{array}$} \\
\hline
\end{tabular}


COMPILATION OF EXISTING CHEMICAL AGENT GUIDELINES - SEPTEMBER 1997

\begin{tabular}{|c|c|c|c|}
\hline Category & $\begin{array}{c}\text { Title } \\
\text { (References footnoted; see page 22) }\end{array}$ & Information & Comments \\
\hline \multicolumn{4}{|c|}{ AIRBORNE EXPOSURE LIMITS (continued) } \\
\hline $\begin{array}{l}\text { Control } \\
\text { Limit }\end{array}$ & $\begin{array}{l}\text { RECOMMENDED ACUTE } \\
\text { THRESHOLD EFFECTS LEVELS FOR } \\
\text { DETERMINING EMERGENCY } \\
\text { EVACUATION DISTANCES IN THE } \\
\text { CSEP PROGRAM IN MILLIGRAM } \\
\text { MINUTES PER CUBIC METER OF AIR } \\
\left(\text { (ng-min/m }{ }^{3}\right) .4 \\
\text { Application: A cumulative exposure that } \\
\text { indicates the point at which civilians are } \\
\text { to be evacuated in the event of a CSEPP } \\
\text { chemical agent release. } \\
\text { See military standard, military no } \\
\text { significant effects dosage. CSEPP } \\
\text { incorporated the military's values after } \\
\text { review by the CDC. }\end{array}$ & $\begin{array}{lc}\text { Agent } & \begin{array}{c}\text { Acute threshold effects } \\
\text { level } \mathbf{m g} \text {-min/ } \mathbf{m}^{3}\end{array} \\
H, H D, H T & \\
L & 2.0 \\
G B & 2.0 \\
V X & 0.5 \\
& 0.4\end{array}$ & $\begin{array}{l}\text { These values will be used with the } \\
\text { Arny's D2PC air dispersion model for } \\
\text { planning the evacuation of civilians in } \\
\text { the event of a CSEPP chemical agent } \\
\text { release. } \\
\text { The CDC feels these values are } \\
\text { protective of public health and safety. } \\
\text { Human exposure to the acute threshold } \\
\text { effects doses of GB and VX is actually a } \\
\text { a lowest-observed-effect-level and could } \\
\text { be exceeded without danger. Significant } \\
\text { adverse effects would not be expected } \\
\text { before considerably higher doses had } \\
\text { been absorbed. }\end{array}$ \\
\hline
\end{tabular}


COMPILATION OF EXISTING CHEMICAL AGENT GUIDELINES - SEPTEMBER 1997

\begin{tabular}{|c|c|c|c|}
\hline Category & $\begin{array}{c}\text { Title } \\
\text { (References footnoted; see page 22) }\end{array}$ & Information & Comments \\
\hline \multicolumn{4}{|c|}{ AIRBORNE EXPOSURE LIMITS (continued) } \\
\hline $\begin{array}{l}\text { Interim } \\
\text { Military } \\
\text { Standard }\end{array}$ & $\begin{array}{l}\text { PROPOSED CHRONIC } \\
\text { REFERENCE CONCENTRATION } \\
\text { (RfCs). } \\
\text { Application: The RfC can be used to } \\
\text { calculate safe concentrations where } \\
\text { persons may be at risk by inhalation } \\
\text { of low levels of chemical agents over } \\
\text { extended periods of time (i.e., chronic } \\
\text { exposures). }\end{array}$ & $\begin{array}{l}\text { These are currently being developed by USACHPPM. } \\
\text { USACHPPM is coordinating this effort with the CDC. }\end{array}$ & $\begin{array}{l}\text { The RfC is translated into acceptable } \\
\text { media concentration levels by } \\
\text { incorporating site-specific exposure } \\
\text { assumptions (exposure factors). These } \\
\text { exposure factors include information } \\
\text { such as exposure frequency, exposure } \\
\text { duration, estimated amount of } \\
\text { contaminated material inhaled, } \\
\text { inhalation rate, and body weight. } \\
\text { These site-specific variables and the } \\
\text { RfC will be incorporated into a health } \\
\text { risk assessment according to USEPA- } \\
\text { approved methodology and } \\
\text { calculations. } \\
\text { RfCs are similar to reference doses } \\
\text { (RfDs). RfCs are applicable for } \\
\text { airborne exposures (i.e., inhalation, or } \\
\text { to breathe in) and RfDs are applicable } \\
\text { for ingestion exposures (i.e., taken into } \\
\text { the body by way of the digestive tract). }\end{array}$ \\
\hline
\end{tabular}


COMPILATION OF EXISTING CHEMICAL AGENT GUIDELINES - SEPTEMBER 1997

\begin{tabular}{|c|c|c|c|c|}
\hline Category & $\begin{array}{c}\text { Title } \\
\text { (References footnoted; see page 22) }\end{array}$ & & Information & Comments \\
\hline \multicolumn{5}{|c|}{ AIRBORNE EXPOSURE LIMITS (continued) } \\
\hline $\begin{array}{l}\text { Military } \\
\text { Standard }\end{array}$ & $\begin{array}{l}\text { MILITARY NO SIGNIFICANT } \\
\text { EFFECTS DOSAGE IN mg-min'm'. } \\
\text { Application: The lowest exposure which } \\
\text { does not produce significant effects in } \\
\text { the general population (to include more } \\
\text { susceptible sub populations) in the } \\
\text { event of a military chemical agent } \\
\text { release. CSEPP incorporated the } \\
\text { military's values as the CSEPP acute } \\
\text { threshold effects level, however, CSEPP } \\
\text { levels did not include a VX inhalation- } \\
\text { deposition limit. }\end{array}$ & $\begin{array}{l}\text { Agent } \\
\text { L/Mustard } \\
G B \\
V X \text { Vapor } \\
V X \text { Inhalation- } \\
\quad \text { Deposition }\end{array}$ & $\begin{array}{l}\text { No significant effects dosage } \\
2.0 \mathrm{mg-min} / \mathrm{m}^{3} \\
0.5 \mathrm{mg}-\mathrm{min} / \mathrm{m}^{3} \\
0.4 \mathrm{mg-min} / \mathrm{m}^{3} \\
0.011 \mathrm{mg} / \mathrm{man}\end{array}$ & $\begin{array}{l}\text { A vapor concentration which indicates } \\
\text { the need to evacuate the general } \\
\text { population in the event of a military } \\
\text { chemical agent release. } \\
\text { The military no significant effects } \\
\text { dosage is that dose at which the general } \\
\text { population would not experience } \\
\text { permanent effects. }\end{array}$ \\
\hline $\begin{array}{l}\text { Military } \\
\text { Standard }\end{array}$ & $\begin{array}{l}\text { MILITARY AIRBORNE EXPOSURE } \\
\text { LIMITS FOR UNMASKED } \\
\text { CHEMICAL AGENT WORKERS IN } \\
\text { mg/m'. } \\
\text { Application: To limit the concentration } \\
\text { of airborne chemical agent in order to } \\
\text { protect the health and safety of the } \\
\text { worker. } \\
\text { These limits are designed to protect the } \\
\text { worker from unsafe concentrations of } \\
\text { chemical agent in the work } \\
\text { environment by establishing a limit } \\
\text { above which respiratory protection is } \\
\text { required. Workers can be exposed to } \\
\text { concentrations at or below these levels } \\
\text { for } 8 \text { hours a day, } 40 \text { hours a week, day } \\
\text { after day, without known adverse health } \\
\text { effects. }\end{array}$ & $\begin{array}{l}\text { Agent } \\
G A / G B \\
G D \\
V X \\
H, H D, H T^{*} \\
L \\
\text { Averaging time: } \\
{ }^{*} \text { All concentrati }\end{array}$ & $\begin{array}{l}\text { Workers } \\
.0001 \mathrm{mg} / \mathrm{m}^{3} \\
.00003 \mathrm{mg} / \mathrm{m}^{3} \\
.00001 \mathrm{mg} / \mathrm{m}^{3} \\
.003 \mathrm{mg} / \mathrm{m}^{3} \\
.003 \mathrm{mg} / \mathrm{m}^{3} \\
8 \mathrm{hr} \text { time weighted average } \\
\text { (TWA) } \\
\text { neasured as } L .\end{array}$ & $\begin{array}{l}\text { If these limits are exceeded, respiratory } \\
\text { protection is required. } \\
\text { The CDC's control limits for chemical } \\
\text { agents for workers have been } \\
\text { incorporated by the military. The } \\
\text { military added standards for GD. }\end{array}$ \\
\hline
\end{tabular}




\section{COMPILATION OF EXISTING CHEMICAL AGENT GUIDELINES - SEPTEMBER 1997}

\begin{tabular}{|c|c|c|c|c|c|}
\hline Category & $\begin{array}{c}\text { Title } \\
\text { (References footnoted; see page 22) }\end{array}$ & \multicolumn{3}{|c|}{ Information } & Comments \\
\hline \multicolumn{6}{|c|}{ AIRBORNE EXPOSURE LIMITS (continued) } \\
\hline $\begin{array}{l}\text { Military } \\
\text { Standard }\end{array}$ & $\begin{array}{l}\text { MILITARY AIRBORNE EXPOSURE } \\
\text { LIMITS FOR NON-AGENT WORKER } \\
\text { AND GENERAL POPULATION IN } \\
\text { mg/m". } \\
\text { Application: To limit the concentration } \\
\text { of airborne chemical agent in order to } \\
\text { protect the health and safety of the non- } \\
\text { agent worker and the general } \\
\text { population. } \\
\text { These limits are designed to protect the } \\
\text { general population (including children } \\
\text { and elderly) from low levels of chemical } \\
\text { agent that may be present in the } \\
\text { environment. Individuals may be } \\
\text { exposed to concentrations at or below } \\
\text { these levels without suffering adverse } \\
\text { effects. }\end{array}$ & $\begin{array}{l}\text { Agent } \\
G A / G B \\
G D \\
V X \\
H, H D, H T * \\
L \\
\text { Averaging time: } \\
\\
\quad{ }^{*} H T \text { is measu } \\
{ }^{* *} \text { All concentr } \\
\text { ***Ceiling value } \\
\quad \text { exposure con }\end{array}$ & $\begin{array}{l}\begin{array}{l}\text { Non-agent } \\
\text { worker and } \\
\text { general } \\
\text { population }\end{array} \\
.000003 \mathrm{mg} / \mathrm{m}^{3} \\
.000003 \mathrm{mg} / \mathrm{m}^{3} \\
.000003 \mathrm{mg} / \mathrm{m}^{3} \\
.0001 \mathrm{mg} / \mathrm{m}^{3} \\
.003 \mathrm{mg} / \mathrm{m}^{3} \\
72 \mathrm{hr} \text { time } \\
\text { weighted } \\
\text { average (TWA) } \\
\text { d as HD. } \\
\text { ons measured as } \\
\text { lormally refers to } \\
\text { entration at any t }\end{array}$ & $\begin{array}{l}\begin{array}{l}\text { Non-agent } \\
\text { worker and } \\
\text { general } \\
\text { population }\end{array} \\
.0001 \mathrm{mg} / \mathrm{m}^{3} \\
.00003 \mathrm{mg} / \mathrm{m}^{3} \\
.00001 \mathrm{mg} / \mathrm{m}^{3} \\
.003 \mathrm{mg} / \mathrm{m}^{3 * *} \\
.003 \mathrm{mg} / \mathrm{m}^{3} \\
* * \text { Ceiling value } \\
\\
\text { e maximum } \\
\text { e, for any duration. }\end{array}$ & $\begin{array}{l}\text { The military incorporated the CDC's } \\
\text { control limits for chemical agents for } \\
\text { the general population. The military } \\
\text { added standards for } G D \text {. } \\
\text { These limits are concentrations which } \\
\text { may reach unprotected people who are } \\
\text { not occupationally exposed and which } \\
\text { are not expected to cause adverse health } \\
\text { or environmental effects. }\end{array}$ \\
\hline
\end{tabular}

Military Standard. A measure established by a military authority; military compliance is mandatory. A limit that cannot be exceeded without endangerment or action. 
COMPILATION OF EXISTING CHEMICAL AGENT GUIDELINES - SEPTEMBER 1997

\begin{tabular}{|c|c|c|c|}
\hline Category & $\begin{array}{l}\text { Title } \\
\text { (References footnoted; see page 22) }\end{array}$ & Information & Comments \\
\hline \multicolumn{4}{|c|}{ AIRBORNE EXPOSURE LIMITS (continued) } \\
\hline $\begin{array}{l}\text { Military } \\
\text { Standard }\end{array}$ & $\begin{array}{l}\text { MILITARY SOURCE STACK } \\
\text { EMISSION LIMITS IN } \mathrm{mg} / \mathrm{m}^{3 .} \\
\text { Application: To restrict incinerator } \\
\text { emissions to concentrations well below } \\
\text { those that would endanger health. }\end{array}$ & $\begin{array}{ll}\text { Agent } & \text { General population } \\
\text { GA/GB } & .0003 \mathrm{mg} / \mathrm{m}^{3} \\
G D & .0001 \mathrm{mg} / \mathrm{m}^{3} \\
V X & .0003 \mathrm{mg} / \mathrm{m}^{3} \\
H, H D, H T & .03 \mathrm{mg} / \mathrm{m}^{3} \\
L & .03 \mathrm{mg} / \mathrm{m}^{3} \\
& \\
& \\
\text { The CDC's control limits for stack emissions are the same } \\
\text { as these limits, except that the CDC did not publish a } \\
\text { value for GD. }\end{array}$ & $\begin{array}{l}\text { Usually allowable stack concentrations } \\
\text { prove more restrictive than a limit set on } \\
\text { health bases alone. These levels have } \\
\text { been evaluated through air dispersion } \\
\text { modeling of worst case credible events } \\
\text { and conditions specific to each site to } \\
\text { ensure that the control limits for } \\
\text { general population and workers would } \\
\text { not be exceeded as a consequence of } \\
\text { releases at or below the allowable stack } \\
\text { concentrations. } \\
\text { These limits are primarily an } \\
\text { engineering standard. These linits } \\
\text { should be attainable by a well-dlesigned, } \\
\text { well-operated incineration facility; give } \\
\text { an early indication of upset conditions; } \\
\text { and be accurately measurable in a } \\
\text { timely manner. }\end{array}$ \\
\hline $\begin{array}{l}\text { Military } \\
\text { Standard }\end{array}$ & $\begin{array}{l}\text { MILITARY NO EFFECTS } \\
\text { CONCENTRATIONS FOR } \\
\text { CHEMICAL AGENTS GA, GB, GD, } \\
\text { AND VXIN mg/mt. } \\
\text { Application: To ensure the protection of } \\
\text { non-related military personnel. These } \\
\text { concentrations are used in modeling } \\
\text { algorithms to calculate hazard zanes to } \\
\text { determine areas of concern when, by } \\
\text { the nature of operations, a release of } \\
\text { agent is expected (such as in the case of } \\
\text { emergency destruction, training, or } \\
\text { maintenance operations). }\end{array}$ & $\begin{array}{l}\text { Workers } \\
.000003 \mathrm{mg} / \mathrm{m}^{3} \\
.000003 \mathrm{mg} / \mathrm{m}^{3} \\
.000003 \mathrm{mg} / \mathrm{m}^{3}\end{array}$ & $\begin{array}{l}\text { The CSEPP acute threshold effects } \\
\text { levels and the military no significant } \\
\text { effects levels are concentrations which } \\
\text { indicate the need to evacuate the } \\
\text { general population in the event of a } \\
\text { military or CSEPP chemical agent } \\
\text { release. The military no effects } \\
\text { concentrations are used by the military } \\
\text { to calculate hazard zones within the } \\
\text { military installation boundaries. }\end{array}$ \\
\hline
\end{tabular}


COMPILATION OF EXISTING CHEMICAL AGENT GUIDELINES - SEPTEMBER 1997

\begin{tabular}{|c|c|c|c|c|c|}
\hline Category & $\begin{array}{c}\text { Title } \\
\text { (References footnoted; see page 22) }\end{array}$ & \multicolumn{3}{|c|}{ Information } & Comments \\
\hline \multicolumn{6}{|c|}{ INGESTION EXPOSURE LIMITS } \\
\hline $\begin{array}{l}\text { Interim } \\
\text { Military } \\
\text { Standard }\end{array}$ & $\begin{array}{l}\text { PROPOSED CHRONIC } \\
\text { REFERENCE DOSES (RfDs) IN } \\
\text { MILLIGRAM CHEMICAL PER } \\
\text { KILOGRAM BODY WEIGHT PER } \\
\text { DAY (mg/kg/day). } \\
\text { Application: The RfD can be used to } \\
\text { calculate safe drinking water levels, } \\
\text { soil clean-up levels, safe food } \\
\text { contaminant levels and other safe } \\
\text { media-specific concentrations where } \\
\text { persons may be at risk by ingestion of } \\
\text { low levels of chemical agent } \\
\text { contaminated media over extended } \\
\text { periods of time (i.e., chronic } \\
\text { exposures). } \\
\text { Proposed RfDs are currently } \\
\text { undergoing review by the Committee } \\
\text { on Toxicology. The proposed RfDs are } \\
\text { for human exposures. }\end{array}$ & $\begin{array}{l}\text { Agent } \\
\text { HD (Sulfur } \\
\text { Mustard } \\
\\
\text { Lewisite } \\
\text { GA (Nerve) } \\
\text { GB (Nerve) } \\
\text { GD (Nerve) } \\
\text { VX (Nerve) } \\
\text { Refer to EP } \\
\text { (RAGS), } 198 \\
\text { contact the } \\
\text { Environmen } \\
\text { U.S. Army C } \\
\text { Preventiv } \\
\text { Aberdeen P } \\
\text { (410) 671-29 }\end{array}$ & $\begin{array}{l}\begin{array}{c}\text { Proposed reference } \\
\text { dose RfD } \\
\text { (mg/kg/day) }\end{array} \\
\text { 7E-06 (0.000007) } \\
\\
\text { 1E-04 (0.0001) } \\
\text { 4E-05 (0.00004) } \\
\text { 2E-05 (0.00002) } \\
\text { 4E-06 (0.000004) } \\
\text { 6E-07 (0.0000006) } \\
\text { Risk Assessment Gu } \\
\text { for application of the } \\
\text { ACHPPM office ind } \\
\text { I Risk Assessment an } \\
\text { iter for Health Prom } \\
\text { Medicine (USACHPP } \\
\text { ing Ground, Maryla } \\
\end{array}$ & $\begin{array}{l}\text { Other } \\
\text { comments } \\
\text { HD is also a } \\
\text { known } \\
\text { human } \\
\text { carcinogen: } \\
\text { proposed Oral } \\
\text { Slope Factor = } \\
\text { 0.095 ( } \mu \mathrm{g} / \mathrm{L})^{-1} \\
\text { proposed } \\
\text { Inhalation Unit } \\
\text { Risk=8.5E-02 } \\
\left.\text { ( } \mu \text { g/m }{ }^{\mathbf{3}}\right)^{-1} \\
\text { lance for Superfund } \\
\text { numbers or } \\
\text { ated.' } \\
\text { Communication } \\
\text { tion and } \\
\text { 1) } \\
\text { d }\end{array}$ & $\begin{array}{l}\text { The RfD is translated into acceptable } \\
\text { media concentration levels by } \\
\text { incorporating site-specific exposure } \\
\text { assumptions (exposure factors). These } \\
\text { exposure factors include information } \\
\text { such as exposure frequency, exposure } \\
\text { duration, estimated amount of } \\
\text { contaminated soil/water/specific food } \\
\text { ingested, ingestion rate, and body } \\
\text { weight. These site-specific variables } \\
\text { and the RfD will be incorporated into } \\
\text { a health risk assessment according to } \\
\text { USEPA- approved methodology and } \\
\text { calculations. USACHPPM is currently } \\
\text { developing a matrix of exposure } \\
\text { factors that can be used to assess } \\
\text { various types of exposure scenarios. } \\
\text { For more information on reference } \\
\text { doses and applications, please see the } \\
\text { USACHPPM Just the Facts } \\
\text { Information Sheet included as } \\
\text { Appendix B to this information } \\
\text { packet. }\end{array}$ \\
\hline
\end{tabular}


COMPILATION OF EXISTING CHEMICAL AGENT GUIDELINES - SEPTEMBER 1997

\begin{tabular}{|c|c|c|c|c|c|}
\hline Category & $\begin{array}{l}\text { Title } \\
\text { (References footnoted; see page 22) }\end{array}$ & \multicolumn{3}{|c|}{ Information } & Comments \\
\hline \multicolumn{6}{|c|}{ INGESTION EXPOSURE LIMITS (continued) } \\
\hline $\begin{array}{l}\text { Military } \\
\text { Guideline }\end{array}$ & $\begin{array}{l}\text { Recommended field drinking } \\
\text { water guidelines for selected } \\
\text { chemical warfare agents in field } \\
\text { drinking water in micrograms per } \\
\text { liter }(\mu \mathrm{g} / \mathrm{L}) / \mathrm{liters} \text { per day (L/day). } \\
\\
\text { Application: A battlefield drinking } \\
\text { water concentration which will } \\
\text { protect military personnel against } \\
\text { acute adverse health effects or } \\
\text { performance-degrading effects } \\
\text { for exposures of up to } 7 \text { days. }\end{array}$ & $\begin{array}{l}\text { Agent } \\
\text { GA }(\mu \mathrm{g} / \mathrm{L}) \\
\text { GB }(\mu \mathrm{g} / \mathrm{L}) \\
\text { GD }(\mu \mathrm{g} / \mathrm{L}) \\
\text { VX }(\mu \mathrm{g} / \mathrm{L}) \\
\text { Sulfur Mustard }(\mu \mathrm{g} / \mathrm{L}) \\
\mathrm{L}\end{array}$ & $\begin{array}{c}\text { commer } \\
5 \text { Lday } \\
70.0 \\
13.8 \\
6.0 \\
7.5 \\
140.0 \\
80.0\end{array}$ & $\begin{array}{l}\text { delines } \\
\text { /day } \\
22.5 \\
4.6 \\
2.0 \\
2.5 \\
47.0 \\
27.0\end{array}$ & $\begin{array}{l}\text { This guideline was developed by } \\
\text { the Committee on Toxicology for } \\
\text { military personnel deployed in the } \\
\text { battlefield and assumes (1) a } 70 \mathrm{~kg} \\
\text { person consumes } 5 \text { to } 15 \mathrm{~L} / \mathrm{day} \text { of } \\
\text { drinking water depending on the } \\
\text { climate, season, and intensity of } \\
\text { work, (2) military personnel are not } \\
\text { expected to be exposed to } \\
\text { chemical agents for more than } 7 \\
\text { days, (3) water contains no other } \\
\text { toxic materials, and (4) there is no } \\
\text { pre-existing cholinesterase (ChE) } \\
\text { inhibition or concurrent use of any } \\
\text { compounds causing ChE } \\
\text { inhibition. } \\
\text { This guideline provides the } \\
\text { necessary flexibility to field } \\
\text { commanders who must weigh the } \\
\text { application of exposure } \\
\text { recommendations against the } \\
\text { need for adequate hydration, } \\
\text { combat readiness, and mission } \\
\text { success. The military recommends } \\
\text { adherence to these guidelines, } \\
\text { however, enforces the military } \\
\text { DoD Tri-service field worker } \\
\text { standards-short-term } \\
\text { consumption. }\end{array}$ \\
\hline
\end{tabular}


COMPILATION OF EXISTING CHEMICAL AGENT GUIDELINES - SEPTEMBER 1997

\begin{tabular}{|c|c|c|c|c|}
\hline Category & $\begin{array}{l}\text { Title } \\
\text { (References footnoted; see page 22) }\end{array}$ & \multicolumn{2}{|c|}{ Information } & Comments \\
\hline \multicolumn{5}{|c|}{$\begin{array}{l}\text { INGESTION EXPOSURE LIMITS (continued) } \\
\text { MILITARY FIELD DRINKING WATER LIMITS (continued) }\end{array}$} \\
\hline $\begin{array}{l}\text { Military } \\
\text { Standard }\end{array}$ & $\begin{array}{l}\text { DOD TRI-SERVICE FIELD WATER } \\
\text { QUALITY STANDARDS - SHORT- } \\
\text { TERM (7 CONSECUTIVE DAYS OR } \\
\text { LESS) IN } \mu \mathrm{g} / L / L / \text { day. } \\
\\
\text { Application: Standards provide for the } \\
\text { short-term safety of exposed military } \\
\text { population based on anticipated } \\
\text { duration of water consumption and the } \\
\text { overall health of the military } \\
\text { population. }\end{array}$ & $\begin{array}{l}\text { Agent } \\
L(\mu g / L) \\
\text { Sulfur Mustard }(\mu g / L) \\
V X, G D, G B, G A(\mu g / L)\end{array}$ & \begin{tabular}{rc}
\multicolumn{2}{c}{ Standard } \\
5 L/day & 15 L/day \\
& \\
80 & 27 \\
140 & 47 \\
12 & 4 \\
&
\end{tabular} & $\begin{array}{l}\text { This standard was developed for } \\
\text { military personnel deployed in } \\
\text { battlefield and assumes: (1) a } 70 \mathrm{~kg} \\
\text { person consumes } 5 \text { to } 15 \text { L/day of } \\
\text { drinking water depending on the } \\
\text { climate season, and intensity of work (2) } \\
\text { exposure would not be more than } \\
7 \text { days, and (3) water contains no other } \\
\text { toxic materials. The military } \\
\text { recommends adherence to the } \\
\text { recommended field drinking water } \\
\text { guidelines, however, the military } \\
\text { enforces these standards. } \\
\\
\text { Note: See Appendix A (page A-21) for } \\
\text { information regarding the DOD Tri- } \\
\text { Service Field Water Quality Standards- } \\
\text { Long-Term. }\end{array}$ \\
\hline
\end{tabular}


COMPILATION OF EXISTING CHEMICAL AGENT GUIDELINES - SEPTEMBER 1997

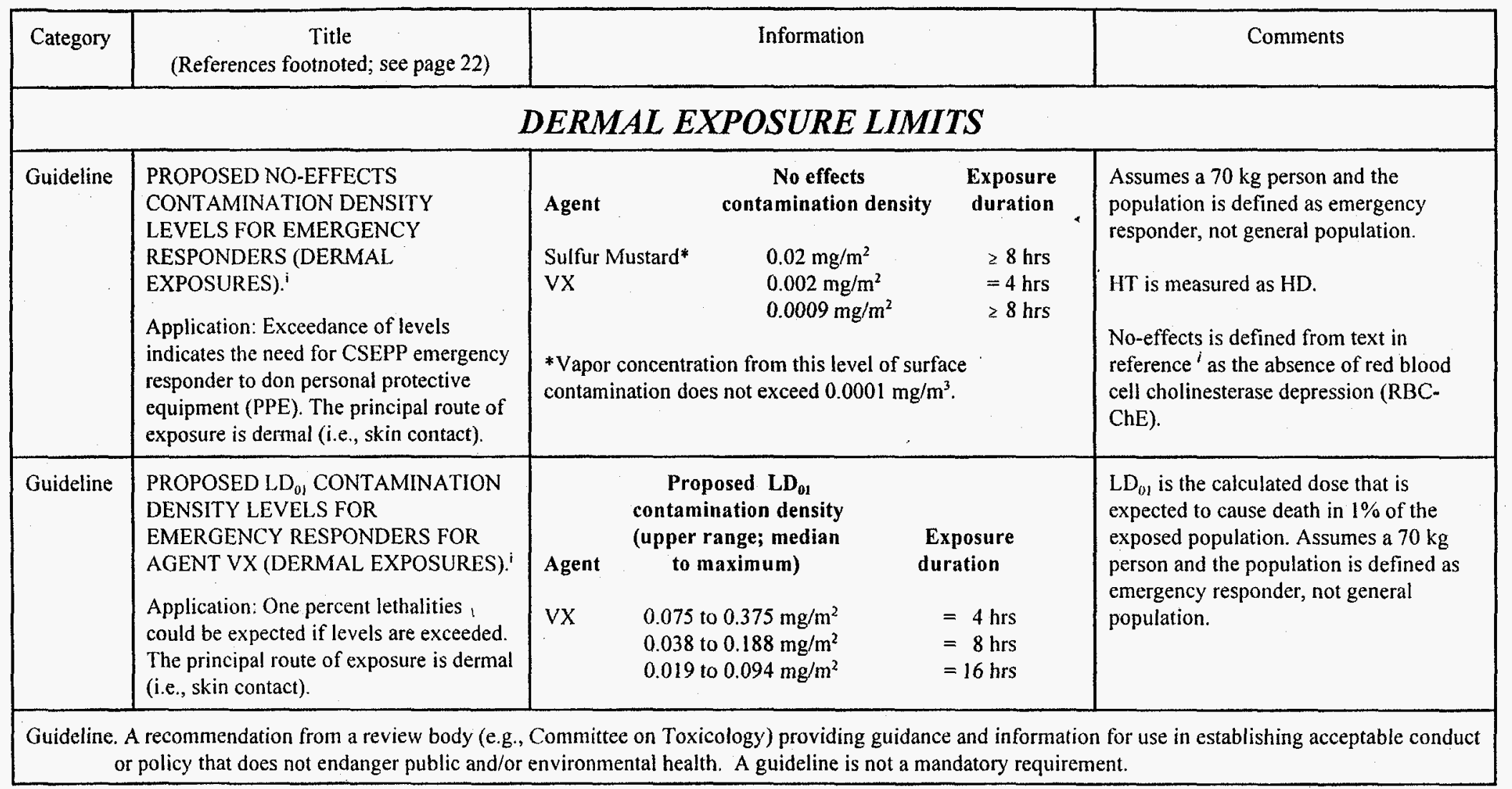




\section{COMPILATION OF EXISTING CHEMICAL AGENT GUIDELINES - SEPTEMBER 1997}

\begin{tabular}{|c|c|c|c|}
\hline Category & $\begin{array}{c}\text { Title } \\
\text { (References footnoted; see page 22) }\end{array}$ & Information & Comments \\
\hline \multicolumn{4}{|c|}{ DECONTAMINATION LIMITS AND PROCESSES } \\
\hline $\begin{array}{l}\text { Military } \\
\text { Standard }\end{array}$ & $\begin{array}{l}\text { MILITARY ALTERNATIVE 5X } \\
\text { MEASUREMENT (OFF-GAS AGENT } \\
\text { CONCENTRATION). } \\
\text { Application: A concentration used to } \\
\text { determine if items (e.g., equipment) } \\
\text { have been decontaminated of the } \\
\text { indicated agent. } \\
\text { 5X is a specific level of } \\
\text { decontamination assigned to items } \\
\text { which have been subject to liquid } \\
\text { contamination or long-term vapor } \\
\text { contamination. The } 5 X \text { procedures will } \\
\text { ensure that the total quantity of agent is } \\
\text { less than the minimal health effects } \\
\text { dosage as determined by the Surgean } \\
\text { General. One approved method for } \\
\text { decontamination is heating the item to } \\
538 \text { degrees C (1000 degrees F) for } 15 \\
\text { minutes. This is considered sufficient } \\
\text { to destroy chemical agent molecules. }\end{array}$ & $\begin{array}{l}\text { An alternative } 5 X \text { methodology (health-risk based release } \\
\text { concentrations) is under development and review by the } \\
\text { DA Steering Committee for Chemical Agent Standards } \\
\text { (USACHPPM lead). }\end{array}$ & $\begin{array}{l}\text { Perform surface decontamination by } \\
\text { CSEPP approved procedures (see } \\
\text { Appendix L of the CSEPP Planning } \\
\text { Guidance). Monitoring is required. } \\
\text { Refer to the Army's Toxic Chemical } \\
\text { Agent Safety Program, DA Pamphlet } \\
\text { 385-61, Chapter } 5 \text { Decontamination } \\
\text { and Disposal for decontamination of } \\
\text { personnel, equipment, and facilities. }\end{array}$ \\
\hline $\begin{array}{l}\text { Military } \\
\text { Standard }\end{array}$ & $\begin{array}{l}\text { MILITARY DECONTAMINATION } \\
\text { PROCEDURES FOR SELF AND } \\
\text { BUDDY. } \\
\text { Application: To provide military } \\
\text { procedures for the decontamination of } \\
\text { personnel. To eliminate an immediate } \\
\text { threat to human life. }\end{array}$ & $\begin{array}{l}\text { Refer to the Army's NBC Decontamination, Field Manual } \\
\text { 3-5; Chemical and Biological Contamination Avoidance, } \\
\text { Field Manual 3-3; Decontamination of Facilities and } \\
\text { Equipment, Technical Bulletin 700-4, and; Toxic } \\
\text { Chemical Agent Safety Program, DA Pamphlet 385-61. }\end{array}$ & $\begin{array}{l}\text { Decontaminate as soon as possible. } \\
\text { Decontaminate as far forward as } \\
\text { possible. Decontaminate by priority. }\end{array}$ \\
\hline
\end{tabular}




\section{COMPILATION OF EXISTING CHEMICAL AGENT GUIDELINES - SEPTEMBER 1997}

\begin{tabular}{|c|c|c|c|}
\hline Category & $\begin{array}{c}\text { Title } \\
\text { (References footnoted; see page 22) }\end{array}$ & Information & Comments \\
\hline \multicolumn{4}{|c|}{ DECONTAMINATION LIMITS AND PROCESSES (continued) } \\
\hline $\begin{array}{l}\text { Military } \\
\text { Standard }\end{array}$ & $\begin{array}{l}\text { MILITARY DECONTAMINATION } \\
\text { PROCEDURES FOR PATIENTS, } \\
\text { HEALTH CARE PROVIDERS, AND } \\
\text { FACILITIES. } \\
\text { Application: To provide military } \\
\text { procedures for the decontamination of } \\
\text { patients at medical stations. Procedures } \\
\text { must be in place to prevent the spread } \\
\text { of contamination to health care } \\
\text { providers and facilities. }\end{array}$ & $\begin{array}{l}\text { Refer to the Army's NBC Decontamination, Field Manual } \\
\text { 3-5; Chemical and Biological Contamination Avoidance, } \\
\text { Field Manual 3-3; Decontamination of Facilities and } \\
\text { Equipment, Technical Bulletin 700-4, and; Toxic } \\
\text { Chemical Agent Safety Program, DA Pamphlet 385-61. }\end{array}$ & $\begin{array}{l}\text { Decontaminate as soon as possible. } \\
\text { Decontaminate as far forward as } \\
\text { possible. Decontaminate by priority. }\end{array}$ \\
\hline $\begin{array}{l}\text { Military } \\
\text { Standard }\end{array}$ & $\begin{array}{l}\text { MILITARY DECONTAMINATION } \\
\text { PROCEDURES FOR EQUIPMENT. } \\
\text { Application: To provide military } \\
\text { procedures for the decontamination of } \\
\text { equipment. }\end{array}$ & $\begin{array}{l}\text { Refer to the Army's NBC Decontamination, Field Manual } \\
\text { 3-5; Chemical and Biological Contamination Avoidance, } \\
\text { Field Manual 3-3; Decontamination of Facilities and } \\
\text { Equipment, Technical Bulletin 700-4, and; Toxic } \\
\text { Chemical Agent Safety Program, DA Pamphlet 385-61. }\end{array}$ & Decontaminate by priority. \\
\hline $\begin{array}{l}\text { Military } \\
\text { Standard }\end{array}$ & $\begin{array}{l}\text { MILITARY DECONTAMINATION } \\
\text { PROCEDURES FOR HUMAN } \\
\text { REMAINS.' } \\
\text { Application: To ensure human remains } \\
\text { have na detectable agent greater than } \\
\text { the military airborne exposure limits for } \\
\text { unmasked chemical agent workers } \\
\text { before release for public burial. }\end{array}$ & $\begin{array}{lc}\text { Agent } & \begin{array}{c}\text { Human remains after } \\
\text { decontamination }\end{array} \\
G A / G B & \\
G D & .0001 \mathrm{mg} / \mathrm{m}^{3} \\
V X & .00003 \mathrm{mg} / \mathrm{m}^{3} \\
H, H D, H T^{*} & .00001 \mathrm{mg} / \mathrm{m}^{3} \\
L & .003 \mathrm{mg} / \mathrm{m}^{3} \\
& .003 \mathrm{mg} / \mathrm{m}^{3} \\
& \\
& \end{array}$ & $\begin{array}{l}\text { Decontamination procedures (i.e., } \\
\text { hypochlorite wash/soak) are performed. } \\
\text { Military gross level detection equipment } \\
\text { is used to determine if gross level } \\
\text { contamination still exists. If not, } \\
\text { remains are checked by low level } \\
\text { detection equipment to confirm remains } \\
\text { meet the required standards. }\end{array}$ \\
\hline
\end{tabular}


COMPILATION OF EXISTING CHEMICAL AGENT GUIDELINES - SEPTEMBER 1997

\begin{tabular}{|c|c|c|c|}
\hline Category & $\begin{array}{l}\text { Title } \\
\text { (References footnoted; see page 22) }\end{array}$ & Information & Comments \\
\hline \multicolumn{4}{|c|}{ DECONTAMINATION LIMITS AND PROCESSES (continued) } \\
\hline $\begin{array}{l}\text { Military } \\
\text { Standard }\end{array}$ & $\begin{array}{l}\text { MILITARY DISPOSAL } \\
\text { PROCEDURES FOR } \\
\text { DECONTAMINATION WASTES. } \\
\text { Application: To ensure } \\
\text { decontamination wastes are managed } \\
\text { and disposed of in accordance with } \\
\text { applicable federal, state, and local laws, } \\
\text { regulations, policies, and procedures. }\end{array}$ & $\begin{array}{l}\text { Refer to the Army's NBC Decontamination, Field Manual } \\
\text { 3-5; Chemical and Biological Contamination Avoidance, } \\
\text { Field Manual 3-3; Decontamination of Facilities and } \\
\text { Equipment, Technical Bulletin } 700-4 \text {, and; Toxic } \\
\text { Chemical Agent Safety Program, DA Pamphlet 385-61. } \\
\text { Refer to the Code of Federal Regulations, Title 49, Parts } \\
171-177, \text { Hazardous Materials Regulations, and Part } 178 \\
\text { Shipping Container Specifications, and; Code of Federal } \\
\text { Regulations, Title 40, Parts } 260-265 \text { and } 270, \text { Regulations } \\
\text { for the Management of Hazardous Waste. } \\
\text { Refer to appropriate state and local laws, regulations, } \\
\text { policies, and procedures. }\end{array}$ & $\begin{array}{l}\text { Refer to the military alternative } 5 X \\
\text { decontamination measurement. }\end{array}$ \\
\hline \multicolumn{4}{|c|}{$\begin{array}{l}\text { Military Standard. A measure established by a military authority; military compliance is mandatory. A limit that cannot be exceeded without endangerment or } \\
\text { action. }\end{array}$} \\
\hline Guideline & $\begin{array}{l}\text { CSEPP SELF AND OTHERS } \\
\text { DECONTAMINATION } \\
\text { PROCEDURES. } \\
\text { Application: To provide guidance on } \\
\text { how to plan (i.e., priorities and } \\
\text { procedures) for decontamination in the } \\
\text { event of a CSEPP chemical agent } \\
\text { release. }\end{array}$ & $\begin{array}{l}\text { Refer to Appendix L (Guideline L.4, page L-7) of the } \\
\text { CSEPP Planning Guidance. }\end{array}$ & $\begin{array}{l}\text { The first decontamination priority is } \\
\text { people; second is essential equipment } \\
\text { (e.g., ambulances), and; third is less } \\
\text { critical assets such as livestock, private } \\
\text { property and croplands. } \\
\text { Decontaminate as soon as possible. } \\
\text { Decontaminate only what is necessary. } \\
\text { Decontaminate as close to the } \\
\text { contaminated area as possible. } \\
\text { Do it fast - do it right! } \\
\text { Refer to military standards for self and } \\
\text { buddy decontamination. }\end{array}$ \\
\hline
\end{tabular}


COMPILATION OF EXISTING CHEMICAL AGENT GUIDELINES - SEPTEMBER 1997

\begin{tabular}{|c|c|c|c|}
\hline Category & $\begin{array}{c}\text { Title } \\
\text { (References footnoted; see page 22) }\end{array}$ & Information & Comments \\
\hline \multicolumn{4}{|c|}{ DECONTAMINATION LIMITS AND PROCESSES (continued) } \\
\hline Guideline & $\begin{array}{l}\text { CSEPP DECONTAMINATION } \\
\text { PROCEDURES FOR PATIENTS, } \\
\text { HEALTH CARE PROVIDERS, AND } \\
\text { FACILITIES. } \\
\text { Application: To provide guidance on } \\
\text { how to plan (i.e., priorities and } \\
\text { procedures) for decontamination of } \\
\text { patients by health care providers in the } \\
\text { event of a CSEPP chemical agent } \\
\text { release. }\end{array}$ & $\begin{array}{l}\text { Refer to Appendix L (Guidelines L.5, L.6, and L.7, starting } \\
\text { page L-8) of the CSEPP Planning Guidance. }\end{array}$ & $\begin{array}{l}\text { The interaction between decontamination } \\
\text { and the provision of medical services is } \\
\text { particulariy important. Medical } \\
\text { attention, including decontamination } \\
\text { must be provided to all people who need } \\
\text { it, however, procedures must be in place } \\
\text { to prevent the spread of contamination to } \\
\text { health care providers and facilities. } \\
\text {. } \\
\text { Refer to military standards for patients, } \\
\text { healthcare providers, and facilities. }\end{array}$ \\
\hline Guideline & $\begin{array}{l}\text { CSEPP RESPONSE PHASE } \\
\text { DECONTAMINATION PROCEDURES } \\
\text { FOR EQUIPMENT." } \\
\text { Application: To provide guidance on } \\
\text { how to plan (i.e., priorities and } \\
\text { procedures) for decontamination of } \\
\text { equipment in the event of a CSEPP } \\
\text { chemical agent release. }\end{array}$ & $\begin{array}{l}\text { Refer to Appendix L (Guideline L.5, page L-8) of the } \\
\text { CSEPP Planning Guidance. }\end{array}$ & $\begin{array}{l}\text { Decontaminate only essential equipment } \\
\text { like ambulances. } \\
\text { Refer to military standards for } \\
\text { equipment. }\end{array}$ \\
\hline Guideline & $\begin{array}{l}\text { CSEPP DECONTAMINATION OF } \\
\text { HUMAN REMAINS.' } \\
\text { Application: To provide guidance on } \\
\text { how to plan (i.e., priorities and } \\
\text { procedures) for the decontamination of } \\
\text { human remains in accordance with all } \\
\text { applicable federal, state, and local laws, } \\
\text { regulations, policies, and procedures in } \\
\text { the event of a CSEPP chemical agent } \\
\text { release. }\end{array}$ & $\begin{array}{l}\text { Refer to Appendix M (Guideline M.5, page M-15) of the } \\
\text { CSEPP Planning Guidance. }\end{array}$ & $\begin{array}{l}\text { Refer to military standards for human } \\
\text { remains. }\end{array}$ \\
\hline
\end{tabular}


COMPILATION OF EXISTING CHEMICAL AGENT GUIDELINES - SEPTEMBER 1997

\begin{tabular}{|c|c|c|c|}
\hline Category & $\begin{array}{l}\text { Title } \\
\text { (References footnoted; see page 22) }\end{array}$ & Information & Comments \\
\hline \multicolumn{4}{|c|}{ DECONTAMINATION LIMITS AND PROCESSES (continued) } \\
\hline Guideline & $\begin{array}{l}\text { CSEPP DISPOSAL OF } \\
\text { DECONTAMINATION WASTES. }{ }^{k} \text {. } \\
\text { Application: To provide guidance on } \\
\text { how to plan (i.e., priorities and } \\
\text { procedures) for the disposal of } \\
\text { decontamination wastes in accordance } \\
\text { with all applicable federal, state, and } \\
\text { local laws, regulations, policies, and } \\
\text { procedures in the event of a CSEPP } \\
\text { chemical agent release. }\end{array}$ & $\begin{array}{l}\text { Refer to Appendix L (Guideline L.5, page L-8) and } \\
\text { Appendix M (Guidelines M.4 and M.5, page M-13) of the } \\
\text { CSEPP Planning Guidance. } \\
\text { Refer to the Code of Federal Regulations, Title } 49 \text {, Parts } \\
171-177 \text {, Hazardous Materials Regulations, and Part } 178 \\
\text { Shipping Container Specifications, and; Code of Federal } \\
\text { Regulations, Title } 40 \text {, Parts } 260-265 \text { and } 270 \text {, Regulations } \\
\text { for the Management of Hazardous Waste. } \\
\text { Refer to appropriate state and local laws; regulations, } \\
\text { policies, and procedures. }\end{array}$ & $\begin{array}{l}\text { Refer to military standards on disposal of } \\
\text { decontamination wastes. }\end{array}$ \\
\hline Guideline & $\begin{array}{l}\text { CSEPP RECOVERY PHASE } \\
\text { DECONTAMINATION } \\
\text { PROCEDURES. k.1 } \\
\text { Application: To provide guidance on } \\
\text { how to plan (i.e., priorities and } \\
\text { procedures) for recovery phase } \\
\text { decontamination in the event of a CSEPP } \\
\text { chemical agent release. }\end{array}$ & $\begin{array}{l}\text { Refer to Appendix M (Guidelines M.2 through M.9, } \\
\text { starting page M-1 1) of the CSEPP Planning Guidance. }\end{array}$ & $\begin{array}{l}\text { Establish a list of priorities like: } \\
\text { (1) critical assets } \\
\text { (2) livestock and companion animals } \\
\text { (3) drinking water } \\
\text { (4) personal property } \\
\text { (5) real estate and terrain } \\
\text { (6) incidental personal property } \\
\text { (7) fodder, feed, and crops }\end{array}$ \\
\hline Guideline & $\begin{array}{l}\text { CSEPP REENTRY AND } \\
\text { RESTORATION } \\
\text { DECONTAMINATION } \\
\text { PROCEDURES. }, 1 \\
\text { Application: To provide guidance on } \\
\text { how to plan (i.e., priorities and } \\
\text { procedures) for reentry and restoration } \\
\text { decontamination in the event of a CSEPP } \\
\text { chemical agent release. }\end{array}$ & $\begin{array}{l}\text { Refer to Appendix } M \text { (Guidelines M.11 through M.18, } \\
\text { starting page } M-25 \text { ) of the CSEPP Planning Guidance. }\end{array}$ & $\begin{array}{l}\text { Establish a list of priorities like: } \\
\text { (1) livestock and companion animals } \\
\text { (2) vegetation used as food, and surface } \\
\text { water sources used as drinking water } \\
\text { (3) surfaces with which humans are } \\
\text { likely to come in contact (e.g., structures, } \\
\text { vehicles) } \\
\text { (4) soil } \\
\text { (5) meat and milk } \\
\text { (6) non-drinking water supplies }\end{array}$ \\
\hline
\end{tabular}


COMPILATION OF EXISTING CHEMICAL AGENT GUIDELINES - SEPTEMBER 1997

\begin{tabular}{|c|c|c|c|}
\hline Category & $\begin{array}{l}\text { Title } \\
\text { (References footnoted; see page 22) }\end{array}$ & Information & Comments \\
\hline \multicolumn{4}{|c|}{ CHEMICAL SURETY LIMITS AND PROCESSES } \\
\hline $\begin{array}{l}\text { Military } \\
\text { Standard }\end{array}$ & $\begin{array}{l}\text { MILITARY CHEMICAL SURETY } \\
\text { LABORATORY SAFETY } \\
\text { STANDARDS. } \\
\text { Application: To ensure laboratory } \\
\text { safety through established military } \\
\text { standards and applicable federal, state, } \\
\text { and local laws, regulations, policies, } \\
\text { and procedures. }\end{array}$ & $\begin{array}{l}\text { Refer to the Army's Toxic Chemical Agent Safety } \\
\text { Program, DA Pamphlet 385-61, and; Nuclear and } \\
\text { Chemical Weapons and Material, Chemical Surety, AR } \\
50-6 . \\
\text { Refer to the Code of Federal Regulations, Title 29, Part } \\
\text { 1450, Occupational Exposure to Hazardous Chemicals in } \\
\text { Laboratories. } \\
\text { Refer to appropriate state and local laws, regulations, } \\
\text { policies, and procedures. }\end{array}$ & $\begin{array}{l}\text { These standards (military and federal) } \\
\text { are a valid method of } \\
\text { eliminating/reducing the unique } \\
\text { hazards associated with research and } \\
\text { development laboratory operations } \\
\text { (agent operations and storage). }\end{array}$ \\
\hline \multicolumn{4}{|c|}{$\begin{array}{l}\text { Military Standard. A measure established by a military authority; military compliance is mandatory. A limit that cannot be exceeded without endangerment } \\
\text { or action. }\end{array}$} \\
\hline Guideline & $\begin{array}{l}\text { CSEPP CHEMICAL SURETY } \\
\text { LABORATORY SAFETY } \\
\text { GUIDELINES. } \\
\text { Application: To provide guidance on } \\
\text { how to plan (i.e., priorities and } \\
\text { procedures) for laboratory safety through } \\
\text { all applicable federal, state, and local } \\
\text { laws, regulations, policies, and } \\
\text { procedures in the event of a CSEPP } \\
\text { chemical agent release. }\end{array}$ & $\begin{array}{l}\text { Refer to Appendix M (Guideline M.16, page M-29) of the } \\
\text { CSEPP Planning Guidance. } \\
\text { Refer to the Code of Federal Regulations, Title 29, Part } \\
1450 \text {, Occupational Exposure to Hazardous Chemicals in } \\
\text { Laboratories. } \\
\text { Refer to appropriate state and local laws, regulations, } \\
\text { policies, and procedures. }\end{array}$ & $\begin{array}{l}\text { Protocols for sample handling and } \\
\text { analysis to ensure accurate and reliable } \\
\text { laboratory results (includes chain of } \\
\text { custody, holding temperatures for } \\
\text { environmental samples, shipping } \\
\text { notification requirements and quality } \\
\text { control procedures, etc.). There are a } \\
\text { limited number of qualified analytical } \\
\text { chemical surety laboratories. } \\
\text { Refer to the military standards for } \\
\text { chemical surety laboratory safety } \\
\text { standards. }\end{array}$ \\
\hline
\end{tabular}


COMPILATION OF EXISTING CHEMICAL AGENT GUIDELINES - SEPTEMBER 1997

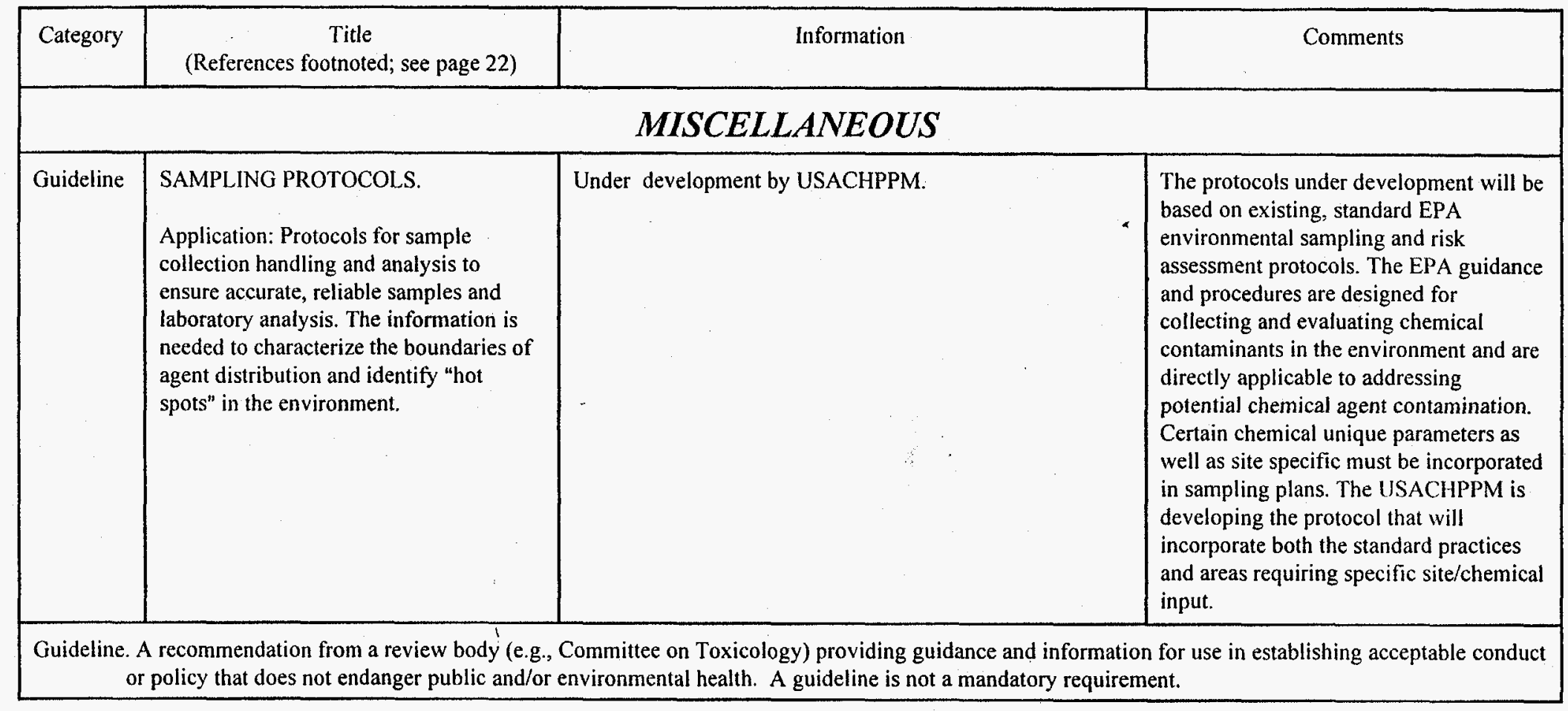




\section{COMPILATION OF EXISTING CHEMICAL AGENT GUIDELINES - SEPTEMBER 1997 REFERENCES}

"The Centers for Disease Control and Prevention (CDC) of the U.S. Department of Health and Human Services (DHHS) 1988. Final Recommendations for Protecting Human Health and Safety Against Potential Adverse Effects of Long-Term Exposure to Low Doses of Agents GA, GB, VX, Mustard Agents (H, HD, HT), and Lewisite (L), Federal Register, Vol. 53 No. 50, page 8504, Tuesday, March 15, 1988 (53 FR 8504).

${ }^{h}$ U.S. Department of the Army (DA). Army Chemical Agent Safety Program, Army Regulation 385-61 (AR 385-61). Army Safety Office, Headquarters, U.S. Department of the Army, Washington, DC (February 21, 1997).

'U.S. Department of the Army (DA). Toxic Chemical Agent Safety Standards, DA Pamphlet 385-61 (DA 385-61). Army Safety Office, Headquarters, U.S. Department of the Army, Washington, DC (March 31, 1997).

'Thacker, Stephen B., M.D., M.Sc., Assistant Surgeon General, Acting Director, National Center for Environmental Health, Centers for Disease Control and Prevention DHHS, letter to Colonel James M. Coverstone, Deputy for Chemical Demilitarization, Office of the Assistant Secretary of the Army Recommended Acute Threshold Effects Levels for CSEPP Program (June 24, 1994).

${ }^{\circ}$ O'Donnell, Francis L., COL MC, Director of Health Services, U.S. Department of the Army, Office of the Surgeon General, memo to Deputy Assistant Secretary of the Army for Environmental Safety, and Occupational Health, et al., Interim Chronic Toxicological Criteria for Chemical Warfare Compounds (Aug 19, 1996). Gaydos, Joel C., COL, MC, Director, Clinical Preventive Medicine, U.S. Department of the Army, Center for Health Promotion and Preventive Medicine, memo to Francis L. O'Donnell, COL, MC, Director of Health Services, U.S. Department of the Army, Office of the Surgeon General, Interim Chronic Toxicological Criteria for Chemical Warfare Compounds (June 4, 1996).

JU.S. Environmental Protection Agency, EPA/540/1-89/002, Risk Assessment Guidance for Superfund Volume I Human Health Evaluation Manual (Part A), Interim Final, Office of Emergency and Remedial Response, Washington, DC, December 1989.

${ }^{8}$ Committee on Toxicology (COT) 1995. Guidelines for Chemical Warfare Agents in Military Field Drinking Water. Subcommittee on Guidelines for Military Field Drinking Water Quality, Committee on Toxicology, National Research Council. National Academy Press, Washington, DC (80pp). 


\section{COMPILATION OF EXISTING CHEMICAL AGENT GUIDELINES - SEPTEMBER 1997 REFERENCES (continued)}

${ }^{h}$ U.S. Department of the Army (DA) (in review). Occupational and Environmental Health: Sanitary Control and Surveillance of Field Water Supplies. TB MED 577, Department of the Army Headquarters, Washington, DC (Draft, June 1996).

'Reutter, S.A., E. J. Olajos, R. J. Mioduszewski and A. Watson 1994. White Paper - Validation of Contact Hazard Toxicity Estimates for Agents VX and HD, Phase II ERDEC-SP-017. Edgewood Research Development Engineering Center, U.S. Army Chemical and Biological Defense Command, Aberdeen Proving Ground, MD (February 1994).

${ }^{j}$ Elam, Fred E., Major General, U.S. Department of the Army, Office of the Deputy Chief of Staff for Logistics, memo to Vice Chief of Staff, Joint Procedures for Decontaminating Human Remains in Operation Desert Storm, (February 26, 1991), U.S. Department of the Army, Office of the Deputy Chief of Staff for Logistics, Washington, DC.

${ }^{k}$ Federal Emergency Management Agency (FEMA) and U.S. Department of Army (DA) 1996. Planning Guidance for the Chemical Stockpile Emergency Preparedness Program, Washington, DC, FEMA 1996.

'Federal Emergency Management Agency (FEMA) and U.S. Department of Army (DA) 1997. Planning Guidelines for Recovery Phase Activity, Appendix M to the Planning Guidance for the Chemical Stockpile Emergency Preparedness Program, Washington, DC, FEMA 1997.

Code of Federal Regulations (CFR), Title 49, Parts 171-177, Hazardous Materials Regulations, and Part 178 Shipping Container Specifications.

Code of Federal Regulations (CFR), Title 40, Parts 260-265 and 270, Regulations for the Management of Hazardous Waste.

Code of Federal Regulations (CFR), Title 29, Part 1450, Occupational Exposure to Hazardous Chemicals in Laboratories.

U.S. Department of the Army (DA) 1993. NBC Decontamination, Field Manual FM 3-5, Headquarters, U.S. Department of the Army, Washington, DC.

U.S. Department of the Army (DA) 1992. Chemical and Biological Contamination Avoidance, Field Manual FM 3-3, Headquarters, U.S. Department of the Army, Washington, DC.

U.S. Department of the Army (DA). Decontamination of Facilities and Equipment, Technical Bulletin TB 700-4, Headquarters, U.S. Department of the Army, Washington, DC. 


\section{COMPILATION OF EXISTING CHEMICAL AGENT GUIDELINES - SEPTEMBER 1997 REFERENCES (continued)}

U.S. Department of the Army (DA). Occupational Health Guidelines for the Evaluation and Control of Occupational Exposure to Nerve Agents $G B, G D$, and VX, DA Pamphlet 40-8 (DA 40-8). Army Safety Office, Headquarters, U.S. Department of the Army, Washington, DC.

U.S. Department of the Army (DA). Occupational Health Guidelines for the Evaluation and Control of Occupational Exposure to Mustard Agents H, HD, and HT, DA Pamphlet 40-173 (DA 40-173). Army Safety Office, Headquarters, U.S. Department of the Army, Washington, DC.

U.S. Department of the Army (DA). Nuclear and Chemical Weapons and Material, Chemical Surety, Army Regulation (AR) 50-6, Headquarters, U.S. Department of the Army, Washington, DC.

U.S. Department of the Army (DA), Headquarters 1991. Chemical Accident/Incident Response and Assistance (CAIRA) Operations, DA Pamphlet 50-6, Commander, U.S. Army Nuclear and Chemical Agency, Springfield, VA.

U.S. Army Center for Health Promotion and Preventive Medicine (USACHPPM). Detailed and General Facts About Chemical Agents TG 218 , Technical Guide 218 (TG 218). U.S. Department of the Army, Aberdeen Proving Ground, MD. 


\section{APPENDIX A}

DETAILED BACKGROUND INFORMATION ON THE COMPILATION OF EXISTING CHEMICAL AGENT GUIDELINES AS OF SEPTEMBER 1997 TABLE 



\section{AIRBORNE EXPOSURE LIMITS}

\section{CATEGORY}

Control Limit

\section{ITEM}

CONTROL LIMITS FOR CHEMICAL AGENTS FOR WORKERS IN MILLIGRAMS PER CUBIC METER OF $A I R\left(m g / m^{3}\right)$.

\section{PURPOSE/USES}

These limits are designed to protect the worker from unsafe concentrations of chemical agent in the work environment. Workers can be exposed to concentrations at or below these levels for 8 hours a day without suffering ill effects. The CDC concludes there to be little risk either of adverse health effects from long-term exposure to low doses or of delayed health effects from acute exposure.

\section{INFORMATION}

$\begin{array}{ll}\text { Agent } & \text { Workers } \\ \text { GA, GB } & 1 \times 10^{-4} \mathrm{mg} / \mathrm{m}^{3} \\ V X & 1 \times 10^{-5} \mathrm{mg} / \mathrm{m}^{3} \\ H, H D, H T & 3 \times 10^{-3} \mathrm{mg} / \mathrm{m}^{3} \\ L & 3 \times 10^{-3} \mathrm{mg} / \mathrm{m}^{3}\end{array}$

Averaging time: $\quad \cdot 8 \mathrm{hr}$ time weighted average (TWA)

\section{REFERENCES}

The Centers for Disease Control and Prevention (CDC) of the U.S. Department of Health and Human Services (DHHS) 1988. Final Recommendations for Protecting Human Health and Safety Against Potential Adverse Effects of Long-Term Exposure to Low Doses of Agents GA, GB, VX, Mustard Agents (H, HD, HT), and Lewisite (L), Federal Register, Vol. 53 No. 50, page 8504, Tuesday, March 15, 1988 (53FR 8504).

\section{COMMENTS}

The CDC stated in their Final Recommendations for Protecting Human Health and Safety Against Potential Adverse Effects of Long-Term Exposure to Low Doses of Agents GA, GB, GD, VX, Mustard Agents (H, HD, HT) and Lewisite (L), that citizens near military depots where chemical weapons are stored expressed concerns about the potential for delayed effects of acute exposure and about the 


\section{ITEM (Continued)}

CONTROL LIMITS FOR CHEMICAL AGENTS FOR WORKERS IN MILLIGRAMS PER CUBIC METER OF $A I R\left(m g / m^{3}\right)$.

\section{COMMENTS}

potential health effects of long-term exposure to low doses of agents. Low dose means an airborne concentration of agent below the control limits.

The CDC concludes human health will be adequately protected from exposure to $G A, G B$, and VX vapor at the concentrations listed. Even long-term exposure to these concentrations would not create any adverse health effects. The CDC concludes the work place limits for mustard agent appear to provide adequate protection for workers during the limited time of potential exposure prior to disposal of these lethal agents.

Almost all (99.97\%) of the vapor released by HT is mustard agent. HT control limits will therefore be identical with those for $H D$ with concentrations measured as $H D$.

The $L$ exposure limits for workers and the general population will remain constant because toxicological information specific to $L$ is sparse. The L limit in air is equivalent to $0.001 \mathrm{mg} / \mathrm{m}^{3}$ measured as arsenic and should be adequate to protect public health. L is an organic compound containing arsenic.

See military standard, military airborne exposure limits for unmasked chemical agent workers. These $C D C$ values have been incorporated by the military. The military added standards for GD. 


\section{AIRBORNE EXPOSURE LIMITS}

\section{CATEGORY}

Control Limit

\section{ITEM}

CONTROL LIMITS FOR CHEMICAL AGENTS FOR THE GENERAL POPULATION IN MILLIGRAMS PER CUBIC METER OF AIR $\left(\mathrm{mg} / \mathrm{m}^{3}\right)$.

\section{PURPOSE/USES}

These limits are designed to protect the general population (including children and elderly) from longterm exposure to low doses of chemical agent. The general population may be exposed to concentrations at or below these levels without suffering effects. The CDC concludes there to be little risk either.of. adverse health effects from long-term exposure to low doses or of delayed health effects from acute. exposure.

\section{INFORMATION}

Agent

$G A, G B$

$V X$

$H, H D, H T$

$L$

Averaging time:

\section{General population}

$3 \times 10^{-6} \mathrm{mg} / \mathrm{m}^{3}$
$3 \times 10^{-6} \mathrm{mg} / \mathrm{m}^{3}$
$1 \times 10^{-4} \mathrm{mg} / \mathrm{m}^{3}$
$3 \times 10^{-3} \mathrm{mg} / \mathrm{m}^{3}$

72 hr time weighted average (TWA)

\section{REFERENCES}

The Centers for Disease Control and Prevention (CDC) of the U.S. Department of Health and Human Services (DHHS) 1988. Final Recommendations for Protecting Human Health and Safety Against Potential Adverse Effects of Long-Term Exposure to Low Doses of Agents GA, GB, VX, Mustard Agents (H, HD, HT), and Lewisite (L), Federal Register, Vol. 53 No. 50, page 8504, Tuesday, March 15, 1988 (53FR 8504). 


\section{ITEM (Continued)}

CONTROL LIMITS FOR CHEMICAL AGENTS FOR THE GENERAL POPULATION IN MILLIGRAMS PER CUBIC METER OF AIR $\left(\mathrm{mg} / \mathrm{m}^{3}\right)$.

\section{COMMENTS}

The CDC stated in their Final Recommendations for Protecting Human Health and Safety Against Potential Adverse Effects of Long-Term Exposure to Low Doses of Agents GA, GB, GD, VX, Mustard Agents (H, HD, HT) and Lewisite (L), that citizens near military depots where chemical weapons are stored expressed concerns about the potential for delayed effects of acute exposure and about the potential health effects of long-term exposure to low doses of agents. Low dose means an airborne concentration of agent below the control limits.

The $C D C$ concludes human health will be adequately protected from exposure to $G A, G B$, and VX vapor at the concentrations listed. Even long-term exposure to these concentrations would not create any adverse health effects. The CDC concludes control of stack emissions and the work place air in accordance with the limits for mustard agent will amply protect the general population 1000 meters or more from a demilitarization site.

Almost all (99.97\%) of the vapor released by HT is mustard agent. HT control limits will therefore be identical with those for $H D$ with concentrations measured as $H D$.

The $L$ exposure limits for workers and the general population will remain constant because toxicological information specific to $L$ is sparse. The L limit in air is equivalent to $0.001 \mathrm{mg} / \mathrm{m}^{3}$ measured as arsenic and should be adequate to protect public health. $L$ is an organic compound containing arsenic.

See military standard, military airborne exposure limits for non-agent workers and general population. The CDC values have been incorporated by the military. The military added standards for GD. 


\section{AIRBORNE EXPOSURE LIMITS}

\section{CATEGORY}

Control Limit

\section{ITEM}

ALLOWABLE STACK CONCENTRATIONS IN MILLIGRAMS PER CUBIC METER OF AIR $\left(\mathrm{mg} / \mathrm{m}^{3}\right)$ FOR CHEMICAL AGENTS.

\section{PURPOSE/USES}

To restrict incinerator emissions to concentrations well below those that would endanger health.

\section{INFORMATION}

Agent

$G A, G B$

$V X$

$H, H D, H T$

$L$

\section{General population}

$3 \times 10^{-4} \mathrm{mg} / \mathrm{m}^{3}$

$3 \times 10^{-4} \mathrm{mg} / \mathrm{m}^{3}$

$3 \times 10^{-2} \mathrm{mg} / \mathrm{m}^{3}$

$3 \times 10^{-2} \mathrm{mg} / \mathrm{m}^{3}$

HT is measured as $H D$.

\section{REFERENCES}

The Centers for Disease Control and Prevention (CDC) of the U.S. Department of Health and Human Services (DHHS) 1988. Final Recommendations for Protecting Human Health and Safety Against Potential Adverse Effects of Long-Term Exposure to Low Doses of Agents GA, GB, VX, Mustard Agents (H, HD, HT), and Lewisite (L), Federal Register, Vol. 53 No. 50, page 8504, Tuesday, March 15, 1988 (53FR 8504).

\section{COMMENTS}

Usually allowable stack concentrations prove more restrictive than a limit set on health bases alone. These levels have been evaluated through air dispersion modeling of worst case credible events and conditions specific to each site to ensure that the control limits for general population and workers would not be exceeded as a consequence of releases at or below the allowable stack concentrations.

These limits are primarily an engineering control limit. These limits should be attainable by a welldesigned, well-constructed, and well-operated incineration facility; give an early indication of upset conditions; and be accurately measurable in a timely manner. 
A-8

\section{AIRBORNE EXPOSURE LIMITS}

\section{CATEGORY}

Military Standard

\section{ITEM}

MILITARY IMMEDIATELY DANGEROUS TO LIFE OR HEALTH (IDLH) VALUE IN MILLIGRAMS PER CUBIC METER OF AIR ( $\left.\mathrm{mg} / \mathrm{m}^{3}\right)$.

\section{PURPOSE/USES}

To indicate to military personnel the levels at which self-contained breathing apparatus (SCBA) or supplied air respirators are required.

\section{INFORMATION}

Agent

$G A, G B$

$G D$

$V X$

\section{Concentration}

$$
\begin{aligned}
& 0.2 \mathrm{mg} / \mathrm{m}^{3} \\
& 0.06 \mathrm{mg} / \mathrm{m}^{3} \\
& 0.02 \mathrm{mg} / \mathrm{m}^{3}
\end{aligned}
$$

${ }^{*} H D / L I D L H$ not formally established since any concentration over the 8 hour $T W A\left(0.003 \mathrm{mg} / \mathrm{m}^{3}\right.$ or $\left.3 \times 10^{-3} \mathrm{mg} / \mathrm{m}^{3}\right)$ requires either a $S C B A$ or supplied air respirator due to concerns over carcinogenicity.

\section{REFERENCES}

U.S. Department of the Army (DA). Army Chemical Agent Safety Program, Army Regulation 385-6I (AR 385-61). Army Safety Office, Headquarters, U.S. Department of the Army, Washington, DC (February 28, 1997).

\section{COMMENTS}

These values were established by the Army Surgeon General for military personnel solely for the purpose of establishing the concentrations at which SCBAs or supplied air respirators are required. IDLH values are only established by the National Institute of Occupational Safety and Health (NIOSH). 


\section{AIRBORNE EXPOSURE LIMITS}

\section{CATEGORY}

Control Limit

\section{ITEM}

RECOMMENDED ACUTE THRESHOLD EFFECTS LEVELS FOR DETERMINING EMERGENCY EVACUATION DISTANCES IN THE CSEPP PROGRAM IN MILLIGRAM MINUTES PER CUBIC METER OF AIR $\left(\mathrm{mg}-\mathrm{min} / \mathrm{m}^{3}\right)$.

\section{PURPOSE/USES}

A cumulative exposure that indicates the point at which civilians are to be evacuated in the event of a CSEPP chemical agent release.

\section{INFORMATION}

\section{Agent}

$H, H D, H T$

$L$

$G B$

$V X$

\section{Acute threshold effect level $\mathrm{mg}-\mathrm{min} / \mathrm{m}^{3}$}

2.0

2.0

0.5

0.4

\section{REFERENCES}

Thacker, Stephen B., M.D., M.Sc., Assistant Surgeon General, Acting Director, National Center for Environmental Health, Centers for Disease Control and Prevention, DHHS, letter to Colonel James $M$. Coverstone, Deputy for Chemical Demilitarization, Office of the Assistant Secretary of the Army Recommended Acute Threshold Effects Levels for CSEPP Program (June 24, 1994).

\section{COMMENTS}

These values will be used with the Army's D2PC air dispersion model for planning the evacuation of civilians in the event of a CSEPP chemical agent release. The CDC feels these values are protective of public health and safety. Human exposure to the acute threshold effects doses of $G B$ and VX is actually at a lowest-observed-effect-level and could be exceeded without danger. Significant adverse effects would not be expected before considerably higher doses had been absorbed.

See military standard, military no significant effects dosage. CSEPP incorporated the military's values after review by the $C D C$. 


\section{CATEGORY}

Interim Military Standard

\section{ITEM}

\section{ARMY PROPOSED CHRONIC REFERENCE CONCENTRATION (RFCs). \\ PURPOSE/USES}

The $\mathrm{RfC}$ can be used to calculate safe concentrations where persons may be at risk by inhalation of low levels of chemical agents over extended periods of time (i.e., chronic exposures).

\section{INFORMATION}

These are currently being developed by USACHPPM. USACHPPM is coordinating this effort with the CDC.

\section{REFERENCES}

O'Donnell, Francis L., COL MC, Director of Health Services, U.S. Department of the Army, Office of the Surgeon General, memo to Deputy Assistant Secretary of the Army for Environmental Safety, and Occupational Health, et al., Interim Chronic Toxicological Criteria for Chemical Warfare Compounds (Aug 19, 1996). Gaydos, Joel C., COL, MC, Director, Clinical Preventive Medicine, U.S. Department of the Army, Center for Health Promotion and Preventive Medicine, memo to Francis L. O'Donnell, COL, MC, Director of Health Services, U.S. Department of the Army, Office of the Surgeon General, Interim Chronic Toxicological Criteria for Chemical Warfare Compounds (June 4, 1996).

\section{COMMENTS}

The $\mathrm{RfC}$ is translated into acceptable media concentration levels by incorporating site-specific exposure assumptions (exposure factors). These exposure factors include information such as exposure frequency, exposure duration, estimated amount of contaminated material inhaled, inhalation rate, and body weight. These site-specific variables and the $\mathrm{RfC}$ will be incorporated into a health risk assessment according to USEPA- approved methodology and calculations.

RfCs are similar to reference doses (RfDs). RfCs are applicable for airborne exposures (i.e., inhalation, or to breathe in) and RfDs are applicable for ingestion exposures (i.e., taken into the body by way of the digestive tract). 


\title{
AIRBORNE EXPOSURE LIMITS
}

\section{CATEGORY}

Military Standard

\section{ITEM}

\author{
MILITARY NO SIGNIFICANT EFFECTS DOSAGE IN MILLIGRAM MINUTES PER CUBIC \\ METER OF AIR $\left(\mathrm{mg}-\mathrm{min} / \mathrm{m}^{3}\right)$.
}

\section{PURPOSE/USES}

The lowest exposure level which does not produce significant effects in the general population (to include more susceptible sub populations) in the event of a military chemical agent release. CSEPP incorporated the military values as the CSEPP acute threshold effects level (after review by the CDC), however, CSEPP levels did not include a VX inhalation-deposition limit.

\section{INFORMATION}

$\begin{array}{ll}\text { Agent } & \text { No significant effects dosage } \\ \text { L/Mustard } & 2.0 \mathrm{mg}-\mathrm{min} / \mathrm{m}^{3} \\ \text { GB } & 0.5 \mathrm{mg}-\mathrm{min} / \mathrm{m}^{3} \\ \text { VX Vapor } & 0.4 \mathrm{mg}-\mathrm{min} / \mathrm{m}^{3} \\ \text { VX Inhalation-Deposition } & 0.011 \mathrm{mg} / \mathrm{man}\end{array}$

\section{REFERENCES}

U.S. Department of the Army (DA). Toxic Chemical Agent Safety Standards, DA Pamphlet 385-61 (DA 385-61). Army Safety Office, Headquarters, U.S. Department of the Army, Washington, DC March 31, 1997).

\section{COMMENTS}

A vapor concentration which indicates the need to evacuate the general population in the event of a military chemical agent release.

The military no significant effects dosage is that dose at which the general population would not experience permanent effects. 


\section{AIRBORNE EXPOSURE LIMITS}

\section{CATEGORY}

Military Standard

\section{ITEM}

MILITARY AIRBORNE EXPOSURE LIMITS FOR UNMASKED CHEMICAL AGENT WORKERS IN MILLIGRAMS PER CUBIC METER OF AIR $\left(\mathrm{mg} / \mathrm{m}^{3}\right)$.

\section{PURPOSE/USES}

To limit the concentration of airborne chemical agent in order to protect the health and safety of the worker. These limits are designed to protect the worker from unsafe concentrations of chemical agent in the work environment by establishing a limit above which respiratory protection is required.,. Workers can be exposed to concentrations at or below these levels for 8 hours a day, 40 hours a week, day after day, without known adverse health effects.

\section{INFORMATION}

$\begin{array}{ll}\text { Agent } & \text { Workers } \\ G A, G B & .0001 \mathrm{mg} / \mathrm{m}^{3} \\ G D & .00003 \mathrm{mg} / \mathrm{m}^{3} \\ V X & .00001 \mathrm{mg} / \mathrm{m}^{3} \\ H, H D, H T^{*} & .003 \mathrm{mg} / \mathrm{m}^{3} \\ L & .003 \mathrm{mg} / \mathrm{m}^{3} \\ & 8 \mathrm{hr} \text { time weighted average (TWA) } \\ \text { Averaging time: } & \\ & \\ \text { *All concentrations are measured as L. }\end{array}$

\section{REFERENCES}

U.S. Department of the Army (DA). Army Chemical Agent Safety Program, Army Regulation 385-61 (AR 385-61). Army Safety Office, Headquarters, U.S. Department of the Army, Washington, DC (February 28, 1997).

\section{COMMENTS}

The CDC's control limits for chemical agents for workers have been incorporated by the military. The military added standards of $G D$. 
ITEM (Continued)

MILITARY AIRBORNE EXPOSURE LIMITS FOR UNMASKED CHEMICAL AGENT WORKERS IN MILLIGRAMS PER CUBIC METER OF AIR $\left(\mathrm{mg} / \mathrm{m}^{3}\right)$.

\section{COMMENTS}

If these limits are exceeded, respiratory protection is required. Refer to Table 2-1 Respiratory Protection Equipment for Regulated Areas in the Army Chemical Agent Safety Program AR 385-61, for the required respiratory equipment at various exposure levels. 


\section{AIRBORNE EXPOSURE LIMITS}

\section{CATEGORY}

Military Standard

\section{ITEM}

MILITARY AURBORNE EXPOSURE LIMITS FOR NON-AGENT WORKER AND GENERAL POPULATION IN MLLIGRAMS PER CUBIC METER OF AIR $\left(\mathrm{mg} / \mathrm{m}^{3}\right)$.

\section{PURPOSE/USES}

To limit the concentration of airborne chemical agent in order to protect the health and safety of the non-agent worker and the general population.

\section{INFORMATION}

Agent

$G A, G B$

$G D$

$V X$

$H, H D, H T^{*}$

$L$

Averaging time:
Non-agent worker and general population

$$
\begin{aligned}
& .000003 \mathrm{mg} / \mathrm{m}^{3} \\
& .000003 \mathrm{mg} / \mathrm{m}^{3} \\
& .000003 \mathrm{mg} / \mathrm{m}^{3} \\
& .0001 \mathrm{mg} / \mathrm{m}^{3} \\
& .003 \mathrm{mg} / \mathrm{m}^{3}
\end{aligned}
$$

72 hr time weighted average (TWA)
Non-agent worker and general population

$$
\begin{aligned}
& .0001 \mathrm{mg} / \mathrm{m}^{3} \\
& .00003 \mathrm{mg} / \mathrm{m}^{3} \\
& .00001 \mathrm{mg} / \mathrm{m}^{3} \\
& .003 \mathrm{mg} / \mathrm{m}^{3 * *} \\
& .003 \mathrm{mg} / \mathrm{m}^{3}
\end{aligned}
$$

${ }^{*} H T$ is measured as HD.

**All concentrations are measured as $L$.

***Ceiling value normally refers to the maximum exposure concentration at any time, for any duration.

\section{REFERENCES}

U.S. Department of the Army (DA). Army Chemical Agent Safety Program, Army Regulation 385-61 (AR 385-61). Army Safety Office, Headquarters, U.S. Department of the Army, Washington, DC (February 28, 1997).

\section{COMMENTS}

The military incorporated the CDC's control limits for chemical agents for the general population. The military added standards for $G D$. 
ITEM (Continued)

MILITARY AIRBORNE EXPOSURE LIMITS FOR NON-AGENT WORKER AND GENERAL POPULATION IN MILLIGRAMS PER CUBIC METER OF AIR $\left(\mathrm{mg} / \mathrm{m}^{3}\right)$.

\section{COMMENTS}

These limits are concentrations which may reach unprotected people who are not occupationally exposed and which are not expected to cause adverse health or environmental effects.

The limits are designed to protect the general population (including children and elderly) from low levels of chemical agent that may be present in the environment. Individuals may be exposed to concentrations at or below these levels without suffering adverse effects. 


\section{AIRBORNE EXPOSURE LIMITS}

\section{CATEGORY}

Military Standard

\section{$\underline{\text { ITEM }}$}

MILITARY SOURCE STACK EMISSION LIMITS IN MILLIGRAMS PER CUBIC METER OF AIR $\left(\mathrm{mg} / \mathrm{m}^{3}\right)$.

\section{PURPOSE/USES}

To restrict incinerator emissions to concentrations well below those that would endanger health.

\section{INFORMATION}

$\begin{array}{ll}\text { Agent } & \text { General population } \\ G A, G B & .0003 \mathrm{mg} / \mathrm{m}^{3} \\ G D & .0001 \mathrm{mg} / \mathrm{m}^{3} \\ V X & .0003 \mathrm{mg} / \mathrm{m}^{3} \\ H, H D, H T & .03 \mathrm{mg} / \mathrm{m}^{3} \\ L & .03 \mathrm{mg} / \mathrm{m}^{3}\end{array}$

\section{REFERENCES}

U.S. Department of the Army (DA). Army Chemical Agent Safety Program, Army Regulation 385-61 (AR 385-61). Army Safety Office, Headquarters, U.S. Department of the Army, Washington, DC (February 28, 1997).

\section{COMMENTS}

Usually allowable stack concentrations prove more restrictive than a limit set on health bases alone. These levels have been evaluated through air dispersion modeling of worst case credible events and conditions specific to each site to ensure that the standards for general population and workers would not be exceeded as a consequence of releases at or below the allowable stack concentrations.

These limits are primarily an engineering standard. These limits should be attainable by a welldesigned, well-operated incineration facility; give an early indication of upset conditions; and be accurately measurable in a timely manner.

The CDC's limits are the same as these limits, except that, the CDC did not publish a value for GD. 


\section{A-17}

\section{AIRBORNE EXPOSURE LIMITS}

\section{CATEGORY}

Military Standard

\section{ITEM}

MILITARY NO EFFECTS CONCENTRATIONS FOR CHEMICAL AGENTS GA, GB, GD, AND VX IN MILLIGRAMS PER CUBIC METER OF AIR $\left(\mathrm{mg} / \mathrm{m}^{3}\right)$.

\section{PURPOSE/USES}

To ensure the protection of non-related military personnel. These concentrations are used in modeling algorithms to calculate hazard zones to determine areas of concern when, by the nature of operations, a release of agent is expected (such as in the case of emergency destruction, training, or maintenance operations).

\section{INFORMATION}

$\begin{array}{ll}\text { Agent } & \text { Concentration }\left(\mathrm{mg} / \mathrm{m}^{3}\right) \\ G A, G B & .000003 \mathrm{mg} / \mathrm{m}^{3} \\ G D & .000003 \mathrm{mg} / \mathrm{m}^{3} \\ V X & .000003 \mathrm{mg} / \mathrm{m}^{3}\end{array}$

\section{REFERENCES}

U.S. Department of the Army (DA). Army Chemical Agent Safety Program, Army Regulation 385-61 (AR 385-61). Army Safety Office, Headquarters, U.S. Department of the Army, Washington, DC (February 28, 1997).

\section{COMMENTS}

The CSEPP acute threshold effects levels and the military no significant effects levels are concentrations which indicate the need to evacuate the general population in the event of a military or CSEPP chemical agent release. The military no effects concentrations are used by the military to calculate hazard zones within the military installation boundaries. 


\title{
CATEGORY
}

Interim Military Standard

\section{$\underline{\text { ITEM }}$}

\begin{abstract}
ARMY PROPOSED CHRONIC REFERENCE DOSES (RFDS) IN MILLIGRAM CHEMICAL PER KILOGRAM BODY WEIGHT PER DAY (mg/kg/day).
\end{abstract}

\section{PURPOSE/USES}

The RfD can be used to calculate safe drinking water levels, soil clean-up levels, safe food contaminant levels and other safe media-specific concentrations where persons may be at risk by ingestion of low levels of chemical agent contaminated media over extended periods of time (i.e., chronic exposures).

\section{INFORMATION}

\section{Agent}

HD (Sulfur Mustard)

Proposed reference dose RfD

$$
\text { (mg/kg/day) }
$$

$$
\text { 7E-06 (0.000007) }
$$

$$
\begin{array}{ll}
1 E-04 & (0.0001) \\
4 E-05 & (0.00004) \\
2 E-05 & (0.00002) \\
4 E-06 & (0.000004) \\
6 E-07 & (0.0000006)
\end{array}
$$

\section{Other comments}

$\mathrm{HD}$ is also a known human carcinogen: proposed Oral Slope Factor $=0.095\left(\mu \mathrm{g} / \mathrm{kg} / \mathrm{day}^{-1}\right.$ proposed Drinking Water Unit Risk = $0.003(\mu \mathrm{g} / \mathrm{L})^{-1}$ proposed Inhalation Unit Risk = 8.5E-02 $\left(\mu \mathrm{g} / \mathrm{m}^{3}\right)^{-1}$

\section{REFERENCES}

O'Donnell, Francis L., COL MC, Director of Health Services, U.S. Department of the Army, Office of the Surgeon General, memo to Deputy Assistant Secretary of the Army for Environmental Safety, and Occupational Health, et al., Interim Chronic Toxicological Criteria for Chemical Warfare Compounds (Aug 19, 1996). Gaydos, Joel C., COL, MC, Director, Clinical Preventive Medicine, U.S. Department of the Army, Center for Health Promotion and Preventive Medicine, memo to Francis L. O'Donnell, COL, MC, Director of Health Services, U.S. Department of the Army, Office of the Surgeon General, Interim Chronic Toxicological Criteria for Chemical Warfare Compounds (June 4, 1996). 
ITEM (Continued)

ARMY PROPOSED CHRONIC REFERENCE DOSES (RfDS) IN MILLIGRAM CHEMICAL PER KILOGRAM BODY WEIGHT PER DAY (mg/kg/day).

\section{COMMENTS}

The RfD is translated into acceptable media concentration levels by incorporating site-specific exposure assumptions (exposure factors). These exposure factors include information such as exposure frequency, exposure duration, estimated amount of contaminated soil/water/specific food ingested, ingestion rate, and body weight. These site-specific variables and the RfD will be incorporated into a health risk assessment according to USEPA- approved methodology and calculations. USACHPPM (http://chppm-www.apgea.army.mil/default.htm) is currently developing a matrix of exposure factors that can be used to assess various exposure scenarios. For more information on reference doses and applications, please see the USACHPPM Just the Facts Information Sheet included as Appendix B to this information packet.

The proposed RfDs are currently undergoing review by the Committee on Toxicology. The proposed RfDs are for human exposures. 
INGESTION EXPOSURE LIMITS

MILITARY FIELD DRINKING WATER LIMITS

\section{CATEGORY}

Military Guideline

ITEM

Recommended field drinking water guidelines for selected chemical warfare agents in field drinking water in micrograms per liters $(\mu \mathrm{g} / \mathrm{L}) /$ liters per day (L/day).

\section{PURPOSE/USES}

A battlefield drinking water concentration which will protect military personnel against acute adverse health effects or performance-degrading effects for exposures of up to 7 days.

\section{INFORMATION}

\section{Agent}

GA $(\mu g / L)$

GB $(\mu \mathrm{g} / \mathrm{L})$

GD $(\mu g / L)$

VX $(\mu \mathrm{g} / L)$

Sulfur Mustard $(\mu \mathrm{G} / L)$

L $(\mu \mathrm{g} / \mathrm{L})$
Recommended guidelines

$$
5 \text { L/day } 15 \text { L/day }
$$

$\begin{array}{rc}70.0 & 22.5 \\ 13.8 & 4.6 \\ 6.0 & 2.0 \\ 7.5 & 2.5 \\ 140.0 & 47.0 \\ 80.0 & 27.0\end{array}$

\section{REFERENCES}

Committee on Toxicology (COT) 1995. Guidelines for Chemical Warfare Agents in Military Field Drinking Water. Subcommittee on Guidelines for Military Field Drinking Water Quality, Committee on Toxicology, National Research Council. National Academy Press, Washington, DC (80pp). 
ITEM (Continued)

Recommended field drinking water guidelines for selected chemical warfare agents in field drinking water in micrograms per liters $(\mu \mathrm{g} / \mathrm{L}) /$ liters per day (L/day).

\section{COMMENTS}

This guideline was developed by the Committee on Toxicology (COT) for military personnel deployed in the battlefield and assumes (1) a $70 \mathrm{~kg}$ person consumes 5 to 15 L/day of drinking water depending on the climate, season, and intensity of work, (2) military personnel are not expected to be exposed to chemical agents for more than 7 days, (3) water contains no other toxic material, and (4) there is no pre-existing cholinesterase ( $\mathrm{ChE}$ ) inhibition or concurrent use of any compounds causing $\mathrm{ChE}$ inhibition.

This guideline provides the necessary flexibility to field commanders who must weigh the application of exposure recommendations against the need for adequate hydration, combat readiness, and mission success. The military recommends adherence to these guidelines, however, enforces the military dod tri-service field water standards-shortterm consumption. 
A-22

INGESTION EXPOSURE LIMITS

MILITARY FIELD DRINKING WATER LIMITS

\section{CATEGORY}

Military Standard

ITEM

DOD TRI-SERVICE FIELD WATER QUALITY STANDARDS-LONG-TERM (LESS THAN I YEAR).

\section{PURPOSE/USES .}

Standards provide for the long-term safety of exposed military population based on anticipated. duration of water consumption and the overall health of the military population.

\section{INFORMATION}

Long-term standards as presented by the military in the Occupational and Environmental Health: Sanitary Control and Surveillance of Field Water Supplies, TBMED577, March 1986, are being superseded and currently under development by USACHPPMs Soldier Exposure Criteria Working Group (see reference below).

\section{REFERENCES}

U.S. Department of the Army (DA) (in review). Occupational and Environmental Health: Sanitary Control and Surveillance of Field Water Supplies. TB MED 577, Department of the Army Headquarters, Washington, DC (Draft, June 1996).

\section{COMMENTS}

There is not yet enough data to set a practical long-term standard. Consumption of contaminated water by military personnel for more than 7 days is unlikely. 
A-23

INGESTION EXPOSURE LIMITS

MILITARY FIELD DRINKING WATER LIMITS

\section{CATEGORY}

Military Standard

\section{ITEM}

DOD TRI-SERVICE FIELD WATER QUALITY STANDARDS-SHORT-TERM (7 CONSECUTIVE DAYS OR LESS) IN MICROGRAMS PER LITER ( $/ \mathrm{g} / L) / L I T E R S$ PER DAY (L/day).

\section{PURPOSE/USES}

Standards provide for the short-term safety of exposed military population based on anticipated duration of water consumption and the overall health of the military population.

\section{INFORMATION}

Agent

\begin{tabular}{|c|c|}
\hline \multicolumn{2}{|c|}{ Standard } \\
\hline 5 L/day & $15 \mathrm{~L} / d a y$ \\
\hline 80.0 & 27.0 \\
\hline 140.0 & 47.0 \\
\hline 12.0 & 4.0 \\
\hline
\end{tabular}

\section{REFERENCES}

U.S. Department of the Army (DA) (in review). Occupational and Environmental Health: Sanitary Control and Surveillance of Field Water Supplies. TB MED 577, Department of the Army

Headquarters, Washington, DC (Draft, June 1996).

\section{COMMENTS}

This standard was developed for military personnel deployed in the battlefield and assumes: (1) a $70 \mathrm{~kg}$ person consumes 5 to $15 \mathrm{~L} /$ day of drinking water depending on the climate, season, and intensity of work (2) exposure would not be more than 7 days, and (3) water contains no other toxic materials.

The recommended field drinking water guidelines were developed by the Committee on Toxicology (COT). The military recommends adherence to the COTs guidelines, however, the military enforces these standards. See page A-21 for DOD Field Water Quality Standards-Long-Term. 
DERMAL EXPOSURE LIMITS

\section{CATEGORY}

Guideline

\section{ITEM}

PROPOSED NO-EFFECTS CONTAMINATION DENSITY LEVELS FOR EMERGENCY RESPONDERS (DERMAL EXPOSURES) IN MILLIGRAMS OF AGENT PER SQUARE METER OF SURFACE AREA $\left(\mathrm{mg} / \mathrm{m}^{2}\right)$.

\section{PURPOSE/USES}

Exceedance of levels indicates the need for CSEPP emergency responders to don personal protective equipment (PPE). The principal route of exposure is dermal (i.e., skin contact).

\section{INFORMATION}

Agent No-effects contamination density Exposure duration

Sulfur Mustard*

$$
\begin{array}{ll}
0.02 \mathrm{mg} / \mathrm{m}^{2} & \geq 8 \mathrm{hrs} \\
0.002 \mathrm{mg} / \mathrm{m}^{2} & =4 \mathrm{hrs} \\
0.0009 \mathrm{mg} / \mathrm{m}^{2} & \geq 8 \mathrm{hrs}
\end{array}
$$

*Vapor concentration from this level of surface contamination does not exceed $0.0001 \mathrm{mg} / \mathrm{m}^{3}$.

\section{REFERENCES}

Reutter, S.A., E. J. Olajos, R. J. Mioduszewski and A. Watson 1994. White Paper - Validation of Contact Hazard Toxicity Estimates for Agents VX and HD, Phase II ERDEC-SP-017. Edgewood Research Development Engineering Center, US Army Chemical and Biological Defense Command, Aberdeen Proving Ground, MD (February 1994).

\section{COMMENTS}

Assumes a $70 \mathrm{~kg}$ person and the population is defined as emergency responder, not general population. $\mathrm{HT}$ is measured as HD.

No-effects is defined from the text in the reference as the absence of red blood cell cholinesterase depression (RBC-ChE). 


\section{$A-25$}

\section{DERMAL EXPOSURE LIMITS}

\section{CATEGORY}

Guideline

\section{ITEM}

PROPOSED LD $D_{01}$ CONTAMINATION DENSITY LEVELS FOR EMERGENCY RESPONDERS FOR AGENT VX (DERMAL EXPOSURES) IN MILLIGRAMS OF AGENT PER SQUARE METER OF SURFACE AREA $\left(\mathrm{mg} / \mathrm{m}^{2}\right)$.

\section{PURPOSE/USES}

One percent lethalities could be expected if levels are exceeded. The principal route of exposure is dermal (i.e., skin contact).

\section{INFORMATION}

Proposed $\mathbf{L D}_{01}$ contamination density

Agent (upper range; median to maximum)

VX

\author{
Exposure duration \\ $=4 \mathrm{hrs}$ \\ $=8 \mathrm{hrs}$ \\ $=16 \mathrm{hrs}$
}

\section{REFERENCES}

Reutter, S.A., E. J. Olajos, R. J. Mioduszewski and A. Watson 1994. White Paper - Validation of Contact Hazard Toxicity Estimates for Agents VX and HD, Phase II ERDEC-SP-017. Edgewood Research Development Engineering Center, US Army Chemical and Biological Defense Command, Aberdeen Proving Ground, MD (February 1994).

\section{COMMENTS}

$\mathrm{LD}_{01}$ is the calculated dose that is expected to cause death in $1 \%$ of the exposed population. Assumes a $70 \mathrm{~kg}$ person and the population is defined as emergency responder, not general population. 


\section{DECONTAMINATION LIMITS AND PROCESSES}

\section{CATEGORY}

Military Standard

ITEM

MILITARY ALTERNATIVE SX DECONTAMINATION MEASUREMENT (OFF-GAS AGENT CONCENTRATION).

\section{PURPOSE/USES}

A concentration used to determine if items (e.g., equipment) have been decontaminated of the indicated agent.

\section{INFORMATION}

An alternative $5 X$ methodology (health-risk based release concentrations) is under development by the DA Steering Committee for Chemical Agent Standards (USACHPPM lead).

\section{REFERENCES}

U.S. Department of the Army (DA). Toxic Chemical Agent Safety Standards, Army Regulation 385-61 (DA 385-61). Army Safety Office, Headquarters, U.S. Department of the Army, Washington, DC (March 31, 1997).

\section{COMMENTS}

$5 X$ is a specific level of decontamination assigned to items which have been subject to liquid contamination or long-term vapor contamination. The $5 X$ procedures will ensure that the total quantity of agent is less than the minimal health effects dosage as determined by the Surgeon General. One approved method for decontamination is heating the item to 538 degrees $C$ (1000 degrees $F$ ) for 15 minutes. This is considered sufficient to destroy chemical agent molecules. Refer to DA Pamphlet 385-61, Chapter 5 Decontamination and Disposal for decontamination of personnel, equipment, and facilities.

Perform surface decontamination according to CSEPP approved procedures (see Appendix $L$ of the CSEPP Planning Guidance). Monitoring is required. 


\section{DECONTAMINATION LIMITS AND PROCESSES}

\section{CATEGORY}

Military Standard

\section{ITEM}

MILITARY DECONTAMINATION PROCEDURES FOR SELF AND BUDDY.

\section{PURPOSES/USES}

To provide military procedures for the decontamination of personnel. To eliminate an immediate threat to human life.

\section{INFORMATION}

Refer to the Army's NBC Decontamination, Field Manual 3-5; Chemical and Biological Contamination Avoidance, Field Manual 3-3; Decontamination of Facilities and Equipment, Technical Bulletin 700-4, and; Toxic Chemical Agent Safety Program, DA Pamphlet 385-61.

\section{REFERENCES}

U.S. Department of the Army (DA) 1993. NBC Decontamination, Field Manual FM 3-5, Headquarters, U.S. Department of the Army, Washington, DC.

U.S. Department of the Army (DA) 1992. Chemical and Biological Contamination Avoidance, Field Manual FM 3-3, Headquarters, U.S. Department of the Army, Washington, DC.

U.S. Department of the Army (DA). Decontamination of Facilities and Equipment, Technical Bulletin TB 700-4, Headquarters, U.S. Department of the Army, Washington, DC.

U.S. Department of the Army (DA). Toxic Chemical Agent Safety Standards, DA Pamphlet 385-61 (DA 385-61). Army Safety Office, Headquarters, U.S. Department of the Army, Washington, DC (March 31, 1997).

\section{COMMENTS}

Decontaminate as soon as possible. Decontaminate as far forward as possible. Decontaminate by priority. 


\section{DECONTAMINATION LIMITS AND PROCESSES}

\section{CATEGORY}

Military Standard

\section{ITEM}

MILITARY DECONTAMINATION PROCEDURES FOR PATIENTS, HEALTH CARE PROVIDERS, AND FACILITIES.

\section{PURPOSES/USES}

To provide military procedures for the decontamination of patients at medical stations. Procedures must be in place to prevent the spread of contamination to health care providers and facilities.

\section{INFORMATION}

Refer to the Army's NBC Decontamination, Field Manual 3-5; Chemical and Biological Contamination Avoidance, Field Manual 3-3; Decontamination of Facilities and Equipment, Technical Bulletin 700-4, and; Toxic Chemical Agent Safety Program, DA Pamphlet 385-61.

\section{REFERENCES}

U.S. Department of the Army (DA) 1993. NBC Decontamination, Field Manual FM 3-5, Headquarters, U.S. Department of the Army, Washington, DC.

U.S. Department of the Army (DA) 1992. Chemical and Biological Contamination Avoidance, Field Manual FM 3-3, Headquarters, U.S. Department of the Army, Washington, DC.

U.S. Department of the Army (DA). Decontamination of Facilities and Equipment, Technical Bulletin TB 700-4, Headquarters, U.S. Department of the Army, Washington, DC.

U.S. Department of the Army (DA). Toxic Chemical Agent Safety Standards, DA Pamphlet 385-61 (DA 385-61). Army Safety Office, Headquarters, U.S. Department of the Army, Washington, DC (March 31, 1997).

\section{COMMENTS}

Decontaminate as soon as possible. Decontaminate by priority. 


\section{DECONTAMINATION LIMITS AND PROCESSES}

\section{CATEGORY}

Military Standard

ITEM

MILITARY DECONTAMINATION PROCEDURES FOR EQUIPMENT.

PURPOSES/USES

To provide military procedures for the decontamination of equipment.

\section{INFORMATION}

Refer to the Army's NBC Decontamination, Field Manual 3-5; Chemical and Biological Contamination Avoidance, Field Manual 3-3; Decontamination of Facilities and Equipment, Technical Bulletin 700-4, and; Toxic Chemical Agent Safety Program, DA Pamphlet 385-61.

\section{REFERENCES}

U.S. Department of the Army (DA) 1993. NBC Decontamination, Field Manual FM 3-5, Headquarters, U.S. Department of the Army, Washington, DC.

U.S. Department of the Army (DA) 1992. Chemical and Biological Contamination Avoidance, Field Manual FM 3-3, Headquarters, U.S. Department of the Army, Washington, DC.

U.S. Department of the Army (DA). Decontamination of Facilities and Equipment, Technical Bulletin TB 700-4, Headquarters, U.S. Department of the Army, Washington, DC.

U.S. Department of the Army (DA). Toxic Chemical Agent Safety Standards, DA Pamphlet 385-61 (DA 385-61). Army Safety Office, Headquarters, U.S. Department of the Army, Washington, DC (March 31, 1997).

\section{COMMENTS}

Decontaminate by priority. 


\section{DECONTAMINATION LIMITS AND PROCESSES}

\section{CATEGORY}

Military Standard

\section{ITEM}

MILITARY DECONTAMINATION PROCEDURES FOR HUMAN REMAINS.

\section{PURPOSES/USES}

To provide military procedures to ensure human remains have no detectable agent greater than the military airborne exposure limits for unmasked chemical agent workers before release for public burial.

\section{INFORMATION}

Agent Human remains after decontamination

$\begin{array}{ll}G A / G B & .0001 \mathrm{mg} / \mathrm{m}^{3} \\ G D & .00003 \mathrm{mg} / \mathrm{m}^{3} \\ V X & .00001 \mathrm{mg} / \mathrm{m}^{3} \\ H, H D, H T^{*} & .003 \mathrm{mg} / \mathrm{m}^{3} \\ L & .003 \mathrm{mg} / \mathrm{m}^{3}\end{array}$

*All concentrations measured as $L$.

\section{REFERENCES}

Elam, Fred E., Major General, U.S. Department of the Army, Office of the Deputy Chief of Staff for Logistics, memo to Vice Chief of Staff, Joint Procedures for Decontaminating Human Remains in Operation Desert Storm, (February 26, 1991), U.S. Department of the Army, Office of the Deputy Chief of Staff for Logistics, Washington, $D C$.

\section{COMMENTS}

Decontamination procedures (i.e., hypochlorite wash/soak) are performed. Military gross level detection equipment is used to determine if gross level contamination still exists. If not, remains are checked by low level detection equipment to confirm remains meet the required standards. 


\section{DECONTAMINATION LIMITS AND PROCESSES}

\section{CATEGORY}

Military Standard

\section{ITEM}

MILITARY DISPOSAL PROCEDURES FOR DECONTAMINATION WASTES.

\section{PURPOSES/USES}

To provide military procedures to ensure decontamination wastes are managed and disposed of in accordance with applicable federal, state, and local laws, regulations, policies, and procedures.

\section{INFORMATION}

Refer to the Army's NBC Decontamination, Field Manual 3-5; Chemical and Biological Contamination Avoidance, Field Manual 3-3; Decontamination of Facilities and Equipment, Technical Bulletin 700-4, and; Toxic Chemical Agent Safety Program, DA Pamphlet 385-61.

Refer to the Code of Federal Regulations, Title 49, Parts 171-177, Hazardous Materials Regulations, and Part 178 Shipping Container Specifications, and; Code of Federal Regulations, Title 40, Parts 260-265 and 270, Regulations for the Management of Hazardous Waste.

Refer to appropriate state and local laws, regulations, policies, and procedures.

\section{REFERENCES}

U.S. Department of the Army (DA) 1993. NBC Decontamination, Field Manual FM 3-5, Headquarters, U.S. Department of the Army, Washington, $D C$.

U.S. Department of the Army (DA) 1992. Chemical and Biological Contamination Avoidance, Field Manual FM 3-3, Headquarters, U.S. Department of the Army, Washington, DC.

U.S. Department of the Army (DA). Decontamination of Facilities and Equipment, Technical Bulletin TB 700-4, Headquarters, U.S. Department of the Army, Washington, DC.

U.S. Department of the Army (DA). Toxic Chemical Agent Safety Standards, DA Pamphlet 385-61 (DA 385-61). Army Safety Office, Headquarters, U.S. Department of the Army, Washington, DC (March 31, 1997). 
ITEM (Continued)

MILITARY DISPOSAL PROCEDURES FOR DECONTAMINATION WASTES.

\section{$\underline{\text { REFERENCES }}$}

Code of Federal Regulations, Title 49, Parts 171-177, Hazardous Materials Regulations, and Part 178 Shipping Container Specifications.

Code of Federal Regulations, Title 40, Parts 260-265 and 270, Regulations for the Management of Hazardous Waste.

\section{COMMENTS}

Refer to the military alternative $5 X$ decontamination measurement. 


\section{DECONTAMINATION LIMITS AND PROCESSES}

\section{CATEGORY}

Guideline

\section{ITEM}

CSEPP SELF AND OTHERS DECONTAMINATION PROCEDURES.

\section{PURPOSES/USES}

To provide guidance on how to plan (i.e., priorities and procedures) for decontamination in the event of a CSEPP chemical agent release.

\section{INFORMATION}

Refer to Appendix L (Guideline L.4, page L-7) of the CSEPP Planning Guidance.

\section{REFERENCES}

Federal Emergency Management Agency (FEMA) and US Department of Army (DA) 1996. Planning Guidance for the Chemical Stockpile Emergency Preparedness Program, Washington, DC, FEMA 1996.

\section{COMMENTS}

The first decontamination priority is people; second is essential equipment (e.g., ambulances), and; third is less critical assets such as livestock, private property, and croplands.

Decontaminate as soon as possible. Decontaminate only what is necessary. Decontaminate as close to the contaminated area as possible.

Do it fast - do it right!

Refer to military standards for self and buddy decontamination. 


\section{DECONTAMINATION LIMITS AND PROCESSES}

\section{CATEGORY}

Guideline

\section{$\because \quad$ ITEM}

CSEPP DECONTAMINATION PROCEDURES FOR PATIENTS, HEALTH CARE PROVIDERS, AND FACILITIES.

\section{PURPOSES/USES}

To provide guidance on how to plan (i.e., priorities and procedures) for decontamination of patients by health care providers in the event of a CSEPP chemical agent release.

\section{INFORMATION}

Refer to Appendix L (Guidelines L.5, L.6, and L.7, starting page L-8) of the CSEPP Planning Guidance.

\section{REFERENCES}

Federal Emergency Management Agency (FEMA) and U.S. Department of Army (DA) 1996. Planning Guidance for the Chemical Stockpile Emergency Preparedness Program, Washington, DC, FEMA 1996.

\section{COMMENTS}

The interaction between decontamination and the provision of medical services in particularly important. Medical attention, including decontamination must be provided to all people who need it, however, procedures must be in place to prevent the spread of contamination to health care providers and facilities.

Refer to military standards for patients, health care providers, and facilities. 


\section{' DECONTAMINATION LIMITS AND PROCESSES}

\section{CATEGORY}

Guideline

\section{ITEM}

CSEPP RESPONSE PHASE DECONTAMINATION PROCEDURES FOR EQUIPMENT.

\section{PURPOSES/USES}

To provide guidance on how to plan (i.e., priorities and procedures) for decontamination of equipment in the event of a CSEPP chemical agent release.

\section{INFORMATION}

Refer to Appendix L (Guidelines L.5 page L-8) of the CSEPP Planning Guidance.

\section{REFERENCES}

Federal Emergency Management Agency (FEMA) and U.S. Department of Army (DA) 1996. Planning Guidance for the Chemical Stockpile Emergency Preparedness Program, Washington, DC, FEMA 1996.

\section{COMMENTS}

Decontaminate only essential equipment like ambulances.

Refer to military standards for equipment. 


\section{DECONTAMINATION LIMITS AND PROCESSES}

\section{CATEGORY}

Guideline

\section{$\because \quad \underline{\text { ITEM }}$}

CSEPP DECONTAMINATION OF HUMAN REMAINS.

\section{PURPOSES/USES}

To provide guidance on how to plan (i.e., priorities and procedures) for the decontamination of human remains in accordance with all applicable federal, state, and local laws, regulations, policies, and procedures in the event of a CSEPP chemical agent release.

\section{INFORMATION}

Refer to Appendix M (Guideline M.5, starting page M-15) of the CSEPP Planning Guidance.

\section{REFERENCES}

Federal Emergency Management Agency (FEMA) and U.S. Department of Army (DA) 1997. Planning Guidelines for Recovery Phase Activity, Appendix M to the Planning Guidance for the Chemical Stockpile Emergency Preparedness Program, Washington, DC, FEMA 1997.

\section{COMMENTS}

Refer to military standards for human remains. 


\section{DECONTAMINATION LIMITS AND PROCESSES}

\section{CATEGORY}

Guideline

\section{ITEM}

\section{CSEPP DISPOSAL OF DECONTAMINATION WASTES.}

\section{PURPOSES/USES}

To provide guidance on how to plan (i.e., priorities and procedures) for the disposal of decontamination wastes in accordance with all applicable federal, state, and local laws, regulations, policies, and procedures in the event of a CSEPP chemical agent release.

\section{INFORMATION}

Refer to Appendix L (Guideline L.5, page L-8) and Appendix M (Guidelines M.4 and M.5, starting page M-13) of the CSEPP Planning Guidance.

Refer to the Code of Federal Regulations, Title 49, Parts 171-177, Hazardous Materials Regulations, and Part 178 Shipping Container Specifications, and; Code of Federal Regulations, Title 40, Parts 260-265 and 270, Regulations for the Management of Hazardous Waste.

Refer to appropriate state and local laws, regulations, policies, and procedures.

\section{REFERENCES}

Code of Federal Regulations (CFR), Title 49, Parts 171-177, Hazardous Materials Regulations, and Part 178 Shipping Container Specifications.

Code of Federal Regulations (CFR), Title 40, Parts 260-265 and 270, Regulations for the Management of Hazardous Waste.

Federal Emergency Management Agency (FEMA) and U.S. Department of Army (DA) 1996. Planning Guidance for the Chemical Stockpile Emergency Preparedness Program, Washington, DC, FEMA 1996.

Federal Emergency Management Agency (FEMA) and U.S. Department of Army (DA) 1997. Planning Guidelines for Recovery Phase Activity, Appendix M to the Planning Guidance for the Chemical Stockpile Emergency Preparedness Program, Washington, DC, FEMA 1997.

\section{COMMENTS}

Refer to military standards on the disposal of decontamination wastes. 


\section{DECONTAMINATION LIMITS AND PROCESSES}

\section{CATEGORY}

Guideline

\section{ITEM}

\section{CSEPP RECOVERY PHASE DECONTAMINATION PROCEDURES.}

\section{PURPOSES/USES}

To provide guidance on how to plan (i.e., priorities and procedures) for recovery phase decontamination in the event of a CSEPP chemical agent release.

\section{INFORMATION}

Refer to Appendix M (Guidelines M.2 through M.9, starting page M-11) of the CSEPP Planning Guidance.

\section{REFERENCES}

Federal Emergency Management Agency (FEMA) and U.S. Department of Army (DA) 1997. Planning Guidelines for Recovery Phase Activity, Appendix M to the Planning Guidance for the Chemical Stockpile Emergency Preparedness Program, Washington, DC, FEMA 1997.

\section{COMMENTS}

Establish a list of priorities like - (1) critical assets, (2) livestock and companion animals, (3) drinking water, (4) personal property, (5) real estate and terrain, (6) incidental personal property, and (7) fodder, feed, and crops. 


\section{DECONTAMINATION LIMITS AND PROCESSES}

\section{CATEGORY}

Guideline

\section{ITEM}

CSEPP REENTRY AND RESTORATION DECONTAMINATION PROCEDURES.

\section{PURPOSES/USES}

To provide guidance on how to plan (i.e., priorities and procedures) for reentry and restoration decontamination in the event of a CSEPP chemical agent release.

\section{INFORMATION}

Refer to Appendix M (Guidelines M.11 through M.18, starting page M-25) of the CSEPP Planning Guidance.

\section{REFERENCES}

Federal Emergency Management Agency (FEMA) and U.S. Department of Army (DA) 1997. Planning Guidelines for Recovery Phase Activity, Appendix M to the Planning Guidance for the Chemical Stockpile Emergency Preparedness Program, Washington, DC, FEMA 1997.

\section{COMMENTS}

Establish a list of priorities like - (1) livestock and companion animals, (2) vegetation used as food, and surface water sources used as drinking water, (3) surfaces with which humans are likely to come in contact (e.g., structures, vehicles), (4) soil, (5) meat and milk, and (6) non-drinking water supplies. 


\section{CHEMICAL SURETY LIMITS AND PROCESSES}

\section{CATEGORY}

Military Standard

\section{ITEM}

MILITARY CHEMICAL SURETY LABORATORY SAFETY STANDARDS.

\section{PURPOSES/USES}

To ensure laboratory safety through established military standards and applicable federal, state, and local laws, regulations, policies, and procedures.

\section{INFORMATION}

Refer to the Army's Toxic Chemical Agent Safety Program, DA Pamphlet 385-61, and; Nuclear and Chemical Weapons and Material, Chemical Surety, AR 50-6.

Refer to the Code of Federal Regulations, Title 29, Part 1450, Occupational Exposure to Hazardous Chemicals in Laboratories.

Refer to appropriate state and local laws, regulations, policies, and procedures.

\section{REFERENCES}

U.S. Department of the Army (DA). Toxic Chemical Agent Safety Standards, DA Pamphlet 385-61 (DA 385-61). Army Safety Office, Headquarters, U.S. Department of the Army, Washington, DC (March 31, 1997).

U.S. Department of the Army (DA). Nuclear and Chemical Weapons and Material, Chemical Surety, Army Regulation (AR) 50-6, Headquarters, U.S. Department of the Army, Washington, DC.

Code of Federal Regulations (CFR), Title 40, Part 1450, Occupational Exposure to Hazardous Chemicals in Laboratories.

\section{COMMENTS}

These standards (military and federal) are a valid method of eliminating/reducing the unique hazards associated with research and development laboratory operations (agent operations and storage). 


\section{CHEMICAL SURETY LIMITS AND PROCESSES}

\section{CATEGORY}

Guideline

\section{ITEM}

\section{CSEPP CHEMICAL SURETY LABORATORY SAFETY GUIDELINES.}

\section{PURPOSE/USES}

To provide guidance on how to plan (i.e, priorities and procedures) for laboratory safety through all applicable federal, state; and local laws, regulations, policies, and procedures in the event of a CSEPP chemical agent release.

\section{INFORMATION}

Refer to Appendix M (Guideline M.16, page M-29) of the CSEPP Planning Guidance.

Refer to Code of Federal Regulations ( $C F R$ ), Title 40, Part 1450, Occupational Exposure to Hazardous Chemicals in Laboratories.

Refer to applicable state and local laws, regulations, policies, and procedures.

\section{REFERENCES}

Code of Federal Regulations (CFR), Title 40, Part 1450, Occupational Exposure to Hazardous Chemicals in Laboratories.

Federal Emergency Management Agency (FEMA) and U.S. Department of Army (DA) 1997. Planning Guidelines for Recovery Phase Activity, Appendix $M$ to the Planning Guidance for the Chemical Stockpile Emergency Preparedness Program, Washington, DC, FEMA 1997.

\section{COMMENTS}

Protocols for sample handling and analysis to ensure accurate and reliable laboratory results (includes chain of custody, holding temperatures for environmental samples, shipping notification requirements and quality control procedures, etc.). There are a limited number of qualified analytical chemical surety laboratories.

Refer to the military standards for chemical surety laboratory safety standards. 


\section{MISCELLANEOUS}

\section{CATEGORY}

Guideline

ITEM

\section{SAMPLING PROTOCOLS.}

\section{PURPOSE/USES}

Protocols for sample collection handling and analysis to ensure accurate, reliable samples and laboratory analysis. The information is needed to characterize the boundaries of agent distribution and identify "hot spots" in the environment.

\section{INFORMATION}

Under development by USACHPPM.

\section{REFERENCES}

\section{COMMENTS}

The protocols under development will be based on existing, standard EPA environmental sampling and risk assessment protocols. The EPA guidance and procedures are designed for collecting and evaluating chemical contaminants in the environment and are directly applicable to addressing potential chemical agent contamination. Certain chemical unique parameters as well as site-specific parameters must be incorporated in sampling plans. The USACHPPM is developing the protocol that will incorporate both the standard practices and areas requiring specific site/chemical input. 


\section{APPENDIX B}

\section{USACHPPM "JUST THE FACTS" INFORMATION SHEET}

ON REFERENCE DOSE 



\section{APPENDIX B \\ USACHPPM "JUST THE FACTS"INFORMATION SHEET ON REFERENCE DOSE SEPTEMBER 1997}

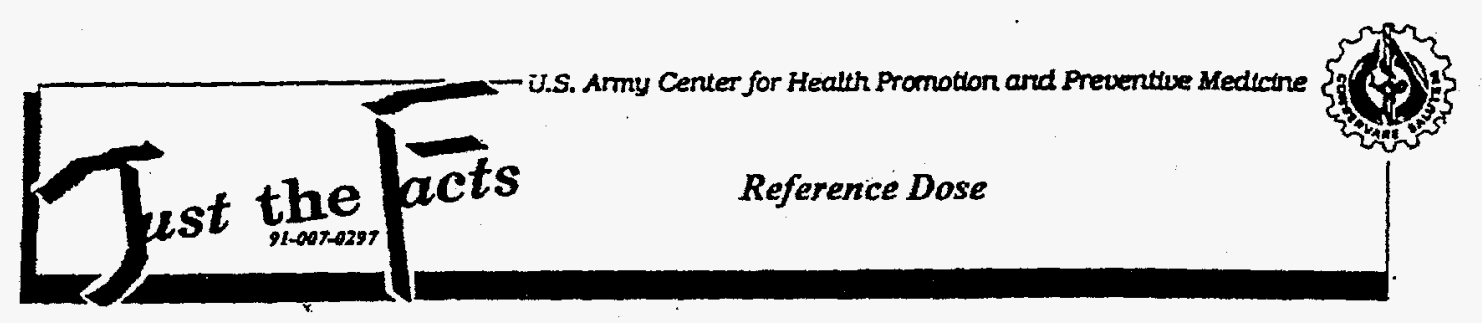

\section{References.}

1. Cicmanec, J.L., M.L. Dourson and R.C. Hertuberg, Noncancer Risk Assessment: Present and Emerging Issues, " Chapter 17, in Fan, A. M and L.W. Chang (eds), Taxicology and Risk Assessment: Principles, Methods, and Appizcations, Marcel Deidker, lnc., New York, NY, 1996.

2. U.S. Eavironmental Protection Agency, EPA/540/1-89/002, Risk Assessment Guidance for Superfund Volume I Human Health Evaluation Mamual (Part A). Interin Finel, Office of Emergency and Remedial Response, Washington, DC, December, 1989.

3. U.S. Environmental Protection Agency, Integrated Risk Information System (IRIS), Onfine. Environmental Criteria and Assessment Office, Cincinnati, OH. 1990.
Reference Dose (RfD). RfD is an estimate, with an uncertainty spanning perhaps an order of magnitude or greater, of a daily exposure level for the buman population, inciuding sensitive subpopulations, that is likely to be without an appreciable risk of deleterious effects during a lifetime. ${ }^{2}$ RfD doses are expressed in units of milligram chemical per kilogram body weight per day (mg/kg/da). They are used in evaluatiog the potential noncarcinogenic effects associated with exposure periods of between 7 years (approximately 10 percent of a human lifetime) and a lifetime. RfDs are applicable to the oral exposure pathway, such as from ingestion of contaminated soil or water. RfDs for the majority of the contaminants of concern at Superfund Program cleanup sites are listed by the United States Environmental Protection Agency (USEPA) in its Integrated Risk Information System (IRIS), or Health Effects Assessment Summary Tables (HEAST).'

Dose-Response Assessments. This is the process of quantitatively evaluating toxicity information and characterizing the relationship between the dose of a contaminant administered or received and the incidence of adverse heaith effects in the exposed population. From a quantitative dose-response relationship, toxicity values are derived that are used in the risk characterization step to estimate the likelihood of adverse effects occurring in humans at different exposure levels ${ }^{2}$. In the case of noncancer critical effects, the USEPA terms this toxicity value the RfD.

Selection of the Critical Data. Estimating an RID for a given compound requires consideration of subchronic or chronic toxicity data, identification of a critical effect, identification of a Lowest-Observed-Adverse Effect Level (LOAEL) or a No-Observed Adverse-Effect Level (NOAEL), and use of the uncertainty factor (UF) and modifying factor (MF) protocol. ${ }^{2}$ All available studies examining the toxicity of a chemical following exposure by the oral route are to be gathered and judged for their scientific merit. Occasionally, studies based on other exposure routes are considered, and the data adjusted for application to the oral route by means of standard assumptions. Any differences between studies are to be reconciled and an overall evaluation reached. If adeijuats human data are available, these should be used as the

Office of the Scientific Advisor 


\section{B-4 \\ APPENDIX B \\ USACHPPM "JUST THE FACTS"INFORMATION SHEET ON REFERENCE DOSE \\ SEPTEMBER 1997}

basis for an RAD. Otherwise, data from animal studies are to be used. ${ }^{2}$ Scientific judgment must be exereised during the seiection process. In the absence of a species that is clearly the most relevant, USEPA assumes that humans are at least as sensitive to the substance as the most sensitive animal species tested. Therefore, as a matter of science policy, the study on the most sensitive species is selected as the critical study for the basis of the RfD.

NOAEL. The NOAEL is the highest experimental dose of a chemical at which there is no statistically or biologically significant increase in frequency or severity of an adverse effect (including the critical toxic effect) in individuals in an exposed group when compared with individuals is an appropriate control group. Sorae effects may be produced at this level, but they are not considered to be adverse, nor precursors to specific adverse effects. The NOAEL is one of the most important data points obtained from the study of the dose-response relationships and is the primary measurement upon which the quantitative assessment of the human risk is based. The NOAEL selection is based in part on the assumption that, if the critical toxic effect is prevented, then all toxic effects are prevented.

LOAEL In dose-response experiments, the LOAEL is defined as the lowest exposure level at which there are statistically or biologically significant increases in frequency or severity of adverse effects between the exposed population and its appropriate control group. ${ }^{2}$ The effect thus characterized, after adjustment for species differences, is referred to as the critical toxic effect. In some studies, only a LOAEL rather than a NOAEL is available.

Selection of UFs and MFs. UFs are adjustments in the NOAEL or LOAEL to accommodate areas of scientific uncertainty inherent in most toxicity data sets. Currently, UFs from 1 to 10 each are applied to extrapolate from animals to humans $\left(\mathrm{UF}_{\mathcal{H}}\right)$, to provide protection for unusually sensitive individuals if the animal species in the critical study is more sensitive to a chemical than humans (UF $)$, to expand from subchronic to chronic exposure $\left(\mathrm{UF}_{\mathrm{s}}\right.$ ), to estimate a NOAEL from the LOAEL (UF,) and to reflect deficiencies in the data base (UF, $\mathrm{U}_{\mathrm{D}}$ ). Lower UFs may be applied in instances where they can be justified. For example, a non-adverse critical effect which is symptomatic of more serious effects at higher levels (e.g., moderate changes in blood cholinesterase levels), requires a lower UF (e.g., UF=3) than adverse toxic effects (e.g., liver damage). In calculating the composite UF, the product should reflect the imprecision of the overall UF determination (e.g., $3 \times 3$ is 10). The maximum total UF applied in the derivation of an RfD is $10,000 .^{\prime}$

There may be additional uncertainties in estimating an RfD such as scientific uncertainties in the key study, study design anornalies, or chemical specific issues. In these instances, an $M F$ greater than zero but $\leq 10$ is applied to account for these considerations. The default value for the MF is 1 .

Deriyation of Reference Dose. The RDD is derived from the NOAEL or LOAEL by consistent application of UFs that reflect various types of data sets used to estimate RfDs. The RfD is calculated as follows:

$$
R I D=\frac{\text { NOAEL OLLOAEL }}{U F_{H} \times U F_{A} \times U F_{S} \times U F_{L} \times U F_{D} \times M F}
$$

Application. The RfD can be used to calculate safe drinking water levels, soil cleanup levels, safe food contarninant levels, and other "safe" media-specific concentrations where persons may be at risk by ingesting contaminated portions of that media. The RfD is translated into these safe media concentrations levels by incorporating site-specific information called exposure factors. These exposure factors include information such as exposure frequency, exposure duration, estimated amount of contaminated soil/water/specific food ingested, ingestion rate, and body weight. These site-specific variables and the RfD are incorporated into a health risk assessment according to USEPA-approved methodologies and calculations." Thus "safe" environmental standards are backcalculated from the toxicological reference point (i.e., the RfD). The actual determination of whether a material is "safe" will te dependent on the situation. 


\section{DISTRIBUTION}

\section{Internal}

1. T. R. Curlee

2. G. E. Courville

3-13. C. B. Foust

14. R. M. Reed

15. R. B. Shelton

16. B. L. Shumpert

17. J. H. Sorensen

18. B. M. Vogt

19. A. P. Watson

20. Central Research Library

21. Laboratory Records- $\mathrm{RC}$

\section{External}

22. Lilia A. Abron, President, PEER Consultants, P.C., 1460 Gulf Blvd., $11^{\text {th }}$ Floor, Clearwater, FL 34630

23. Thomas E. Drabek, Proffessor, Department of Sociology, University of Denver, Denver, CO 80208-0209

24. Louis Restreppo, Omicron, P. O. Box 93065, Albuquerque, NM 87199-3065

25. Allen Riordan, Department of Marine, Earth, and Atmospheric Sciences, North Carolina State University, P.O. Box 8208, Raleigh, NC 27695-8208

26. P. Richard Rittlemann, FAIA, Executive Vice President, Burt Hill Kosar Rittleman Associates, 400 Morgan Center, Butler, PA 16001-5977

27. Susan F. Tierney, The Economic Resource Group, Inc., One Mifflin Place, Cambridge, MA 02138

28. C. Michael Walton, Ernest H. Cockrell Centennial Chair In Engineering and Chairman, Department of Civil Engineering, University of Texas at Austin, Austin, Texas 78712-1076

29-30. Office of Assistant Manager of Energy \& Development, P.O. Box 2001, Oak Ridge, TN 37831 6269

31. Office of Scientific and Technical Information, P.O. Box 62, Oak Ridge, TN 37831

32. ORNL Site Manager, U.S. Department of Energy, Oak Ridge National Laboratory, P.O. Box 2008, Oak Ridge, TN 37831-6269

33. John L. Murray, Jr., Safety Director, Baystate Health System, Springfield, MA 01199

34. Janet L. Thiem, DuPont Nonwovens - TYVEK, Laurel Run Building, P.O. Box 80,705, Wilmington, DE 19880-0705

35. Michael Ziskin, President, Field Safety Corporation, 579 Lake Drive., Suite 101 Guildford, CT 06437 